\title{
Hazardous cyanobacteria integrity response to velocity gradient and powdered activated carbon in water treatment plants.
}

OLIVEIRA, S., CLEMENTE, A., MENEZES, I., GOIS, A., CARLOTO, I., LAWTON, L. and CAPELO-NETO, J. 


\title{
Hazardous cyanobacteria integrity response to velocity gradient and powdered activated carbon in water treatment plants
}

Samylla Oliveira $^{1 *}$, Allan Clemente ${ }^{1}$, Indira Menezes ${ }^{1}$, Amanda Gois $^{1}$, Ismael Carloto ${ }^{2}$, Linda Lawton $^{3}$, Jose Capelo-Neto ${ }^{1}$

samylla_17@hotmail.com; allan.clemente@alu.ufc.br; indiramenezesc@gmail.com; gois.amanda.viana@gmail.com; ismael.lopes@ifce.edu.br; 1.lawton@rgu.ac.uk; capelo@ufc.br

${ }^{1}$ Federal University of Ceara, Department of Hydraulic and Environmental Engineering, Block 713, Campus Pici, Fortaleza, Ceará, Brazil.

${ }^{2}$ Federal Institute of Education, Science, and Technology of Ceará - Campus Acaraú. Av. Des. Armando de Sales Louzada, s/n. Acaraú, Ceará, Brazil.

${ }^{3}$ Robert Gordon University, Sir Ian Wood Building, Garthdee Road. Aberdeen, United Kingdom.

*Corresponding author: capelo@ufc.br, +55 8533669180

\begin{abstract}
Although some studies have investigated the impact caused by chemicals used on water treatment (coagulants and oxidants) on cyanobacteria integrity, the isolated effect of shear stress during coagulation is still not fully understood. This study evaluated the impact of different velocity gradients, mixing times, and the addition of powdered activated carbon (PAC) on the integrity of Microcystis aeruginosa, Raphidiopsis raciborskii, and Dolichospermum circinale, known producers of toxin and taste and odor (T\&O) compounds. No association was found between $R$. raciborskii cell lysis and velocity gradient, with or without PAC, demonstrating the high resilience of this taxon to shear stress. In contrast, an association was found for M. aeruginosa at the highest velocity gradient evaluated $\left(1000 \mathrm{~s}^{-1}\right)$ and for D. circinale above the lowest velocity gradient studied $\left(600 \mathrm{~s}^{-1}\right)$. After PAC addition,
\end{abstract}


there was a reduction in the chances of finding $M$. aeruginosa intact cells above velocity gradient $800 \mathrm{~s}^{-1}$ at $45 \mathrm{~s}$, while $D$. circinale show cell lysis in all the scenarios expect at $600 \mathrm{~s}^{-1}$ and $10 \mathrm{~s}$ of agitation. The additional impact of PAC on cell lysis may lead to more release of metabolites and shows the need to adjust the hydraulic conditions in the rapid mixing stage, especially when more -fragilell cyanobacteria are present. Neither cyanobacterial cell size nor morphology was shown to be relevant to shear stress sensitivity, indicating that cell wall composition might have been an important factor in controlling cell lysis.

Keywords: Microcystis aeruginosa, Raphidiopsis raciborskii, and Dolichospermum circinale; drinking water treatment; flash mixing; shear stress; cell integrity.

\section{Introduction}

The rapid anthropic eutrophication aggravated by climate change has made cyanobacteria blooms more frequent and intense, challenging existing water treatment plant (WTP) processes to effectively produce drinking water that is safe and aesthetically acceptable (Bullerjahn et al., 2016; Duran-Encalada et al., 2017; Paerl et al., 2016a; Trenberth et al., 2014). In tropical regions, for example, toxin-producing filamentous cyanobacteria, among them $R$. raciborskii, have been dominating the phytoplankton community of artificial reservoirs, with average cell concentrations of around $10^{6}$ cells $\mathrm{mL}^{-1} . D$. circinale and $M$. aeruginosa have also been of major concern to water companies in these regions (Barros et al., 2017).

Conventional treatments (e.g., coagulation, flocculation, sedimentation, filtration, and disinfection) have multiple barriers that aim to remove colloids, pathogens, and suspended particles, such as cyanobacteria but are generally not designed to remove dissolved compounds (toxins and $\mathrm{T} \& \mathrm{O}$ compounds). In addition to the cell lysis that occurs naturally in the reservoir, several physical and chemical stresses may cause damage to the cyanobacteria membrane throughout the treatment steps, thereby increasing the solubilization of their intracellular content (Szlag et al., 2015; Zamyadi et al., 2015). In this case, WTPs that use water from highly 
eutrophic reservoirs may produce drinking water with concentrations of toxins and T\&O compounds above guideline thresholds, leading to the rejection of the finished water due to the unpleasant organoleptic characteristics or to the potential toxicity

(Chernova et al., 2019, 2017; Paerl et al., 2016a). Additionally, the increase of soluble organic matter and secondary metabolites increases WTP chemical requirements and the potential to form disinfection by-products during the treatment process (Ho et al., 2012). Optimization of the WTP process to remove intact cyanobacterial cells should significantly reduce the costs and risks involved in the treatment process (Sun et al., 2012; Zamyadi et al., 2015).

Different species of cyanobacteria require different strategies during water treatment operations. According to Li et al. (2018), due to greater sensitivity to chemical stresses, $R$. raciborskii and $D$. circinale showed a higher chance of metabolite release during coagulation and sludge storage when compared to M. aeruginosa. Pestana et al. (2019) studied three fullscale WTPs and also found that cyanobacteria trichome damage was species-dependent. Cyanobacteria with larger trichrome length (Planktothrix sp., Geitlerinema sp. and Dolichospermum sp.) were more prone to breakage than short-trichomed ones (Pseudanabaena sp. and Planktolyngbya sp.). Clemente et al. (2020) evaluated the cellular and trichome integrity of two filamentous cyanobacteria during the rapid-mixing step and found that $D$. circinale was significantly affected while $R$. raciborskii showed no signs of damage.

Although few researchers have studied the effect of coagulants and oxidants on the integrity of cyanobacteria (Bakheet et al., 2018; Naceradska et al., 2017; Xie et al., 2016; Zhou et al., 2014), the isolated impact of the shear stress due to hydraulic conditions applied during the coagulation step on the cell integrity of $R$. raciborskii, D. circinale, and M. aeruginosa has not been fully understood. Rodriguez et al. (2009) reported that excessive shear stress can cause reduced cell growth and productivity, severe cell damage, and even cell lysis, which could be particularly challenging for sensitive species. 
Sensitivity to shear differs between species and is dependent on multiple factors including cell size, presence of flagella, morphology, and composition of the cell wall (Rodriguez et al., 2009). However, contradictory results in the literature highlight the complexity of microalgal behavior and that systematic studies under controlled conditions are still needed to gain a thorough understanding of the effects of the competing parameters (Norsker et al., 2011).

The proposed hypothesis is that shear stress, imposed by the velocity gradient necessary for coagulation, can impose integrity loss on cyanobacteria cells and that the higher the velocity gradient and the longer the organisms are subjected to it, the more likely organisms are to be damaged. Moreover, powdered activated carbon (PAC), added during the coagulation step to remove dissolved secondary metabolites, may increase the chances of cyanobacteria cell damage due to the mechanical stress they add to the suspension during flash mixing.

The objective of this study was to evaluate the impact of velocity gradient, agitation time, and PAC addition on $R$. raciborskii, D. circinale, and $M$. aeruginosa cell integrity in order to identify which of these variables could be managed so that organism damage and intracellularcontent release could be minimized.

\section{Materials And Methods}

\subsection{Cyanobacterial cultures}

Three cyanobacteria, $R$. raciborskii, D. circinale, and $M$. aeruginosa were selected based on their presence in surface reservoirs in several countries and on their potential to produce undesired secondary metabolites (Barros et al., 2017; Haakonsson et al., 2017; Sinha et al., 2012).

The species were isolated from surface reservoirs in Northeast Brazil and cultured in ASM-1 medium (Gorham et al., 1964) with $\mathrm{pH} 8$, in non-axenic conditions, but with imperceptible bacterial contamination under conventional microscopic analysis. The species were kept under 
a white light intensity of $6.75 \mu . \mathrm{mol} . \mathrm{m}^{-2} . \mathrm{s}^{-1}$ (Digital Light Meter YF-1065, China), temperature of $24 \pm 2^{\circ} \mathrm{C}$, and photoperiod of $12: 12$ hours (light/dark) for $21 \pm 2$ days. M. aeruginosa grew in unicellular spherical form and cells with an average diameter of $2.5 \mu \mathrm{m}$.

R. raciborskii was composed of chained filaments, known as trichomes, with an average length of $75 \mu \mathrm{m}$, while $D$. circinale also exhibited straight filamentous morphology but with an average length of $15 \mu \mathrm{m}$, both without mucilaginous sheaths.

\subsection{Cell density and integrity analysis}

Cell density was measured according to APHA-AWWA-WEF (2005) using an inverted optical microscope (Zeiss Vert.A1, Germany) and a Sedgewick-Rafter chamber. Counting was performed across bands or fields with a magnification of $20 \mathrm{x}$ or $40 \mathrm{x}$, allowing a confidence interval of $95 \% \pm 20 \%$. To quantify the number of cells per trichome and determine the length of filaments, 30 filaments were randomly chosen and evaluated immediately after each experiment using an optical microscope (Olympus Optical, Model: Cx-31, Brazil). Cell counting was performed immediately before the experiments, therefore, no stain or fixative was added to the samples.

Cell integrity was evaluated by a staining method using 5\% erythrosine-B (Dynamics, Brazil) by Clemente et al. (2020) with a magnification of 40x. Erythrosine- $\mathrm{B}\left(\mathrm{C}_{20} \mathrm{H}_{6} \mathrm{I}_{4} \mathrm{Na}_{2} \mathrm{O}_{5}\right)$ is a nontoxic, biological dye that can be used to identify damaged living cells (Clemente et al., 2020; Calomeni and Rodgers, 2015; DiBartolomeis and Mone, 2004; Markelova et al., 2000). In a cell with an intact membrane, erythrosine-B is not absorbed and maintains its original appearance. On the other hand, in cells with compromised integrity, erythrosine-B penetrates, and accumulates in the cytoplasm, producing a pink color easily distinguished under optical microscopy (Markelova et al., 2000). In our experiment, 100 cells of $M$. aeruginosa and $D$. circinale and 100 trichomes of $R$. raciborskii were randomly selected and counted in 
triplicate to improve the statistical power of each sample. In total, for each species, 10,800 organisms were evaluated totaling 32,400 cell integrity results.

\subsection{Experimental design}

Each strain of M. aeruginosa, D. circinale, and R. raciborskii were separately cultured in ASM1 medium and diluted with dechlorinated treated water (Supplementary Materials contains the basic water quality data) until the final concentration of $10^{6}$ cells $\mathrm{mL}^{-1}$ (Fan et al., 2014; Qi et al., 2016; Zhou et al., 2014). Continuous stirred reactors were used to evaluate the impact of different velocity gradients and mixing times on the cellular structure of the selected species. The velocity gradients applied were $600 \mathrm{~s}^{-1}(270 \mathrm{rpm}), 800 \mathrm{~s}^{-1}(345 \mathrm{rpm})$, and $1000 \mathrm{~s}^{-1}$ (420 rpm) at mixing times of $10,15,30,45$, and 60 seconds. These parameters were based on the coagulation conditions (Velocity Gradient $600-1000 \mathrm{~s}^{-1}$; Mixing times $10-60 \mathrm{~s}$ ) suggested by AWWA and ASCE, (2012). All experiments were performed in triplicate.

In the second phase of the experiment, PAC (Coconut-based; bulk density $=425 \mathrm{~kg} \mathrm{~m}^{-3}$; mean particle diameter $=30 \mu \mathrm{m}$ ) was added to the reactors under the same conditions applied in the previous phase, to observe the impact of carbon particles on the cyanobacterial cell structure. A PAC dose of $30 \mathrm{mg} \mathrm{L}^{-1}$ was applied since it is commonly used in both the experimental and full-scale (Kim et al., 2014). The simplified experimental protocol is presented in Figure 1.

Figure 1 - Simplified experimental protocol. (A) represents the species cultivation; (B) shows the experiments using different velocity gradients, mixing times, and PAC addition; (C) represents the identification of cell integrity. 


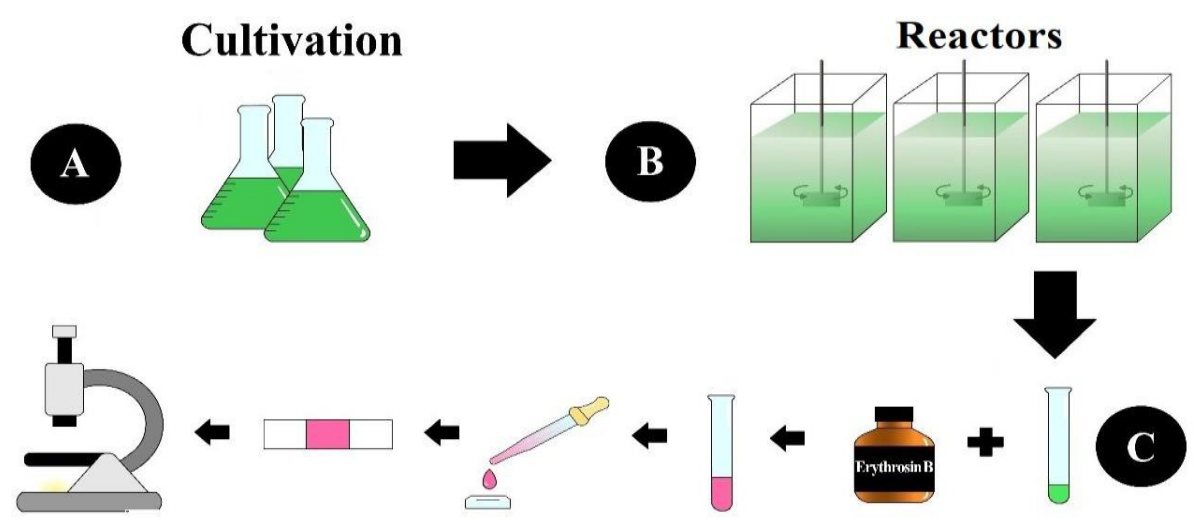

Cell Integrity Assessment

\subsection{Data analyses}

Statistical analyses to evaluate the hypothesis of the association between the variables (cyanobacteria species, velocity gradient interval, mixing time, and with or without PAC addition) and cell integrity was performed using RStudio and modified data analysis methodology (Clemente et al., 2020). Details on these data analyses can be found in the Supplementary Materials.

\section{Results And Discussion}

\subsection{Identifying association between cell integrity and experimental variables}

Tables 1, 2, and 3 present the mean and standard deviation of intact cyanobacteria cells after exposure to velocity gradients G1 $\left(600 \mathrm{~s}^{-1}\right), \mathrm{G} 2\left(800 \mathrm{~s}^{-1}\right)$ and G3 $\left(1000 \mathrm{~s}^{-1}\right)$, with and without added PAC and at mixing times of 10, 15, 30, 45 and $60 \mathrm{~s}$. In these tables, the results of Fisher's exact test were incorporated, to compare the impacts of different mixing times to the initial condition $(\mathrm{t}=0 \mathrm{~s})$. The association between cell integrity and any variable was considered significant when $p<0.05$.

R. raciborskii cell integrity was not compromised in any experimental condition (Table 1), even with the most intense velocity gradient, highest mixing time, and after PAC addition. Therefore, there is no evidence that mechanical stress imposed by the hydraulic condition 
usually applied in WTPs are capable of compromising $R$. raciborskii cells. The cellular integrity of $M$. aeruginosa (Table 2) was only affected by intense velocity gradient (G3 [1000] $\mathrm{s}^{-1}$ ), without PAC, and at relatively long times (45 and $60 \mathrm{~s}$ ). Reductions of up to $4 \%$ in the number of intact cells in the other scenarios were not considered significant. Table 3 shows sufficient statistical evidence that, without PAC, velocity gradients above G2 ([800] s ${ }^{-1}$ ) may cause a reduction in the number of $D$. circinale intact cells. With the introduction of PAC, starting from G1 ([600] s $\left.{ }^{-1}\right)$ and mixing time of $15 \mathrm{~s}$, there was a sharp drop in the number of $D$. circinale intact cells. The results show that $D$. circinale is more sensitive to mechanical stress caused by the hydraulic conditions than $R$. raciborskii and $M$. aeruginosa and that the presence of PAC intensifies this effect.

Shear stress has been shown to cause filament breakage in different filamentous cyanobacteria. Spirulina platensis and Aphanizomenon flos-aquae, for example, displayed shear sensitivity compared to green algae and other cyanobacteria (Bronnenmeier and Märkl, 1982; Leupold et al., 2013). Our results contradict the Wang and Lan (2018) study which gathered enough evidence to suggest that filamentous phytoplankton displayed greater shear sensitivity than unicellular ones.

Although it has been hypothesized that larger microalgae are possibly more sensitive to shear stress than smaller ones (Camacho et al., 2001), this was also not true in our study since the largest cyanobacteria in our study, $R$. raciborskii, was the least affected by shear stress.

Table 1 - Impact of mixing conditions and PAC on R raciborskii cell integrity (mean \# intact cells/100, SD, Fisher's statistic).

Raphidiopsis raciborskii

PAC Velocity gradient $\quad$ Time of mix




\begin{tabular}{|c|c|c|c|c|c|c|c|c|}
\hline & $\left(\mathrm{s}^{-1}\right)$ & & $0 \mathrm{~s}$ & $10 \mathrm{~s}$ & $15 \mathrm{~s}$ & $30 \mathrm{~s}$ & $45 \mathrm{~s}$ & $60 \mathrm{~s}$ \\
\hline \multirow{6}{*}{ Without } & 600 & $\begin{array}{l}\text { Mean } \\
\text { (SD) }\end{array}$ & $\begin{array}{l}100 \\
(0.00\end{array}$ & $\begin{array}{c}100 \\
(0.00\end{array}$ & $\begin{array}{l}100 \\
(0.00\end{array}$ & $\begin{array}{c}100 \\
(0.00\end{array}$ & $\begin{array}{c}100 \\
(0.00\end{array}$ & $\begin{array}{r}100 \\
(0.00\end{array}$ \\
\hline & & $P$ & - & 1 & 1 & 1 & 1 & 1 \\
\hline & 800 & $\begin{array}{l}\text { Mean } \\
\text { (SD) }\end{array}$ & $\begin{array}{c}100 \\
(0.00 \\
)\end{array}$ & $\begin{array}{c}100 \\
(0.00\end{array}$ & $\begin{array}{c}100 \\
(0.00\end{array}$ & $\begin{array}{c}100 \\
(0.00\end{array}$ & $\begin{array}{c}100 \\
(0.00\end{array}$ & $\begin{array}{c}100 \\
(0.00 \\
)\end{array}$ \\
\hline & & $P$ & - & 1 & 1 & 1 & 1 & 1 \\
\hline & 1000 & $\begin{array}{l}\text { Mean } \\
\text { (SD) }\end{array}$ & $\begin{array}{c}100 \\
(0.00 \\
)\end{array}$ & $\begin{array}{r}100 \\
(0.00\end{array}$ & $\begin{array}{c}100 \\
(0.00\end{array}$ & $\begin{array}{c}100 \\
(0.00\end{array}$ & $\begin{array}{c}100 \\
(0.00\end{array}$ & $\begin{array}{r}100 \\
(0.00\end{array}$ \\
\hline & & $P$ & - & 1 & 1 & 1 & 1 & 1 \\
\hline \multirow{5}{*}{ With } & 600 & $\begin{array}{l}\text { Mean } \\
\text { (SD) }\end{array}$ & $\begin{array}{r}100 \\
(0.00\end{array}$ & $\begin{array}{r}100 \\
(0.00\end{array}$ & $\begin{array}{c}100 \\
(0.00\end{array}$ & $\begin{array}{c}100 \\
(0.00\end{array}$ & $\begin{array}{c}100 \\
(0.00\end{array}$ & $\begin{array}{r}100 \\
(0.00\end{array}$ \\
\hline & & $P$ & - & 1 & 1 & 1 & 1 & 1 \\
\hline & 800 & $\begin{array}{l}\text { Mean } \\
(\mathrm{SD})\end{array}$ & $\begin{array}{c}100 \\
(0.00 \\
)\end{array}$ & $\begin{array}{c}100 \\
(0.00 \\
)\end{array}$ & $\begin{array}{c}100 \\
(0.00 \\
)\end{array}$ & $\begin{array}{c}100 \\
(0.00 \\
)\end{array}$ & $\begin{array}{c}100 \\
(0.00 \\
)\end{array}$ & $\begin{array}{c}100 \\
(0.00 \\
)\end{array}$ \\
\hline & & $P$ & - & 1 & 1 & 1 & 1 & 1 \\
\hline & 1000 & $\begin{array}{l}\text { Mean } \\
(\mathrm{SD})\end{array}$ & $\begin{array}{c}100 \\
(0.00 \\
)\end{array}$ & $\begin{array}{c}100 \\
(0.00 \\
)\end{array}$ & $\begin{array}{c}100 \\
(0.00 \\
)\end{array}$ & $\begin{array}{c}100 \\
(0.00 \\
)\end{array}$ & $\begin{array}{c}100 \\
(0.00 \\
)\end{array}$ & $\begin{array}{c}100 \\
(0.00 \\
)\end{array}$ \\
\hline
\end{tabular}


Table 2 Impact of mixing conditions and PAC on M. aeruginosa cell integrity (mean \# intact cells/100, SD, Fisher's statistic)

\section{Microcystis aeruginosa}

\begin{tabular}{|c|c|c|c|c|c|c|c|c|}
\hline \multirow{2}{*}{ PAC } & \multirow{2}{*}{$\begin{array}{l}\text { Velocity gradient } \\
\qquad\left(\mathrm{s}^{-1}\right)\end{array}$} & & \multicolumn{6}{|c|}{ Time of mix } \\
\hline & & & $0 \mathrm{~s}$ & $10 \mathrm{~s}$ & $15 \mathrm{~s}$ & $30 \mathrm{~s}$ & $45 \mathrm{~s}$ & $60 \mathrm{~s}$ \\
\hline \multirow{11}{*}{ Without } & & Mean & 100 & 99 & 100 & 97 & 97 & 97 \\
\hline & 600 & (SD) & $(0.58)$ & $(0.58)$ & $(0.00)$ & $(0.58)$ & $(0.58)$ & $(0.58)$ \\
\hline & & $P$ & - & 1 & 1 & 0.246 & 0.246 & 0.246 \\
\hline & & Mean & 99 & 98 & 98 & 97 & 97 & 96 \\
\hline & 800 & (SD) & $(1.15)$ & $(1.15)$ & $(1.53)$ & $(2.65)$ & $(0.58)$ & $(0.58)$ \\
\hline & & $P$ & - & 1 & 1 & 1 & 1 & 0.369 \\
\hline & & & 99 & & & & & \\
\hline & & Mean & & 96 & 94 & 94 & 91 & 92 \\
\hline & 1000 & (SD) & & $(1.15)$ & $(1.53)$ & $(0.00)$ & $(2.52)$ & $(2.08)$ \\
\hline & & & $(0.58)$ & & & & & \\
\hline & & $P$ & - & 0.369 & 0.120 & 0.120 & 0.018 & 0.035 \\
\hline \multirow{6}{*}{ With } & & Mean & 100 & 100 & 100 & 99 & 97 & 96 \\
\hline & 600 & (SD) & $(0.58)$ & $(0.00)$ & $(0.58)$ & $(0.00)$ & $(1.53)$ & $(0.58)$ \\
\hline & & $P$ & - & 1 & 1 & 1 & 0.246 & 0.121 \\
\hline & & Mean & 100 & 99 & 96 & 96 & 97 & 96 \\
\hline & 800 & (SD) & $(0.58)$ & $(0.58)$ & $(0.58)$ & $(1.53)$ & $(1.73)$ & $(1.53)$ \\
\hline & & $P$ & - & 1 & 0.121 & 0.121 & 0.246 & 0.121 \\
\hline
\end{tabular}




\begin{tabular}{cccccccc} 
& Mean & 100 & 99 & 99 & 98 & 97 & 96 \\
1000 & $(\mathrm{SD})$ & $(0.58)$ & $(0.00)$ & $(0.00)$ & $(0.58)$ & $(1.00)$ & $(1.00)$ \\
\cline { 2 - 7 } & $P$ & - & 1 & 1 & 0.497 & 0.246 & 0.121
\end{tabular}

Table 3 - Impact of mixing conditions and PAC on D. circinale cell integrity (mean \# intact cells/100, SD, Fisher's statistic)

\section{Dolichospermum circinale}

\begin{tabular}{|c|c|c|c|c|c|c|c|c|}
\hline \multirow{2}{*}{ PAC } & \multirow{2}{*}{$\begin{array}{c}\text { Velocity } \\
\text { gradient } \\
\left(\mathrm{s}^{-1}\right)\end{array}$} & & \multicolumn{6}{|c|}{ Time of Mix } \\
\hline & & & $0 \mathrm{~s}$ & $10 \mathrm{~s}$ & $15 \mathrm{~s}$ & $30 \mathrm{~s}$ & $45 \mathrm{~s}$ & $60 \mathrm{~s}$ \\
\hline \multirow{6}{*}{ Without } & 600 & $\begin{array}{l}\text { Mean } \\
\text { (SD) }\end{array}$ & $\begin{array}{c}80 \\
(8.62)\end{array}$ & $\begin{array}{c}77 \\
(7.64)\end{array}$ & $\begin{array}{c}84 \\
(6.66)\end{array}$ & $\begin{array}{c}80 \\
(8.14)\end{array}$ & $\begin{array}{c}85 \\
(14.30 \\
)\end{array}$ & $\begin{array}{c}74 \\
(1.15)\end{array}$ \\
\hline & & $p$ & - & 0.731 & 0.581 & 1 & 0.457 & 0.401 \\
\hline & 800 & $\begin{array}{l}\text { Mean } \\
\text { (SD) }\end{array}$ & $\begin{array}{c}62 \\
(2.52)\end{array}$ & $\begin{array}{c}39 \\
(14.40)\end{array}$ & $\begin{array}{c}49 \\
(16.92)\end{array}$ & $\begin{array}{c}60 \\
(17.24 \\
)\end{array}$ & $\begin{array}{c}40 \\
(8.89)\end{array}$ & $\begin{array}{c}41 \\
(3.51)\end{array}$ \\
\hline & & $p$ & - & 0.002 & 0.088 & 0.885 & 0.003 & 0.005 \\
\hline & 1000 & $\begin{array}{l}\text { Mean } \\
\text { (SD) }\end{array}$ & $\begin{array}{c}96 \\
(3.61)\end{array}$ & $\begin{array}{c}93 \\
(4.04)\end{array}$ & $\begin{array}{c}85 \\
\\
(3.61)\end{array}$ & $\begin{array}{c}82 \\
(1.00)\end{array}$ & $\begin{array}{c}84 \\
(4.36)\end{array}$ & $\begin{array}{c}68 \\
(8.89)\end{array}$ \\
\hline & & $p$ & - & 0.537 & 0.014 & 0.002 & 0.008 & $<0.001$ \\
\hline With & 600 & $\begin{array}{l}\text { Mean } \\
\text { (SD) }\end{array}$ & $\begin{array}{c}91 \\
(2.08)\end{array}$ & $\begin{array}{c}83 \\
(1.73)\end{array}$ & $\begin{array}{c}75 \\
(3.79)\end{array}$ & $\begin{array}{c}71 \\
(2.00)\end{array}$ & $\begin{array}{c}59 \\
(3.21)\end{array}$ & $\begin{array}{c}53 \\
(2.65)\end{array}$ \\
\hline
\end{tabular}




\begin{tabular}{|c|c|c|c|c|c|c|c|}
\hline & $p$ & - & 0.140 & 0.004 & $\begin{array}{c}<0.00 \\
1\end{array}$ & $\begin{array}{c}<0.00 \\
1\end{array}$ & $<0.001$ \\
\hline 800 & $\begin{array}{l}\text { Mean } \\
(\mathrm{SD})\end{array}$ & $\begin{array}{c}92 \\
(5.57)\end{array}$ & $\begin{array}{c}81 \\
(9.64)\end{array}$ & $\begin{array}{c}77 \\
(2.08)\end{array}$ & $\begin{array}{c}78 \\
(2.08)\end{array}$ & $\begin{array}{c}72 \\
(2.89)\end{array}$ & $\begin{array}{c}34 \\
(6.36)\end{array}$ \\
\hline & $p$ & - & 0.037 & 0.006 & 0.009 & $\begin{array}{c}<0.00 \\
1\end{array}$ & $<0.001$ \\
\hline & $\begin{array}{l}\text { Mean } \\
\text { (SD) }\end{array}$ & $\begin{array}{c}93 \\
(5.57)\end{array}$ & $\begin{array}{c}77 \\
(9.64)\end{array}$ & $\begin{array}{c}76 \\
(2.08)\end{array}$ & $\begin{array}{c}69 \\
(2.08)\end{array}$ & $\begin{array}{c}56 \\
(2.89)\end{array}$ & $\begin{array}{c}45 \\
(6.36)\end{array}$ \\
\hline & $p$ & - & 0.002 & 0.001 & $\begin{array}{c}<\mathbf{0 . 0 0} \\
1\end{array}$ & $\begin{array}{c}<0.00 \\
1\end{array}$ & $<0.001$ \\
\hline
\end{tabular}

Cell walls provide structural support, protective covering, and play a role in shear sensitivity (Barbosa et al., 2003). Most green algae contain a cellulose-rich cell wall, which provides a rigid and resilient covering, but cyanobacterial cell walls normally consist of three to four layers mainly composed of peptidoglycan (Gumbo et al., 2008). Interestingly, green algae Chlamydomonas reinhardtii is cellulose-deficient and quite sensitive to shear stress (Jeanneret et al., 2016).

M. aeruginosa cell wall is divided into several layers: the cytoplasmic membrane, the peptidoglycan layer, and the multilayered structure of the cell wall composed of polysaccharides, which lend rigidity to the cell wall (Woitzik et al., 1988). The literature contains a very limited amount of information about the cell wall composition of $D$. circinale or $R$. raciborskii.

As a proxy to D. circinale cell wall composition, we examined the composition of Anabaena cylindrica cells as presented by Dunn and Wolk (1970). The vegetative cell wall contained 
amino compounds $(65 \%)$, lipid $(3 \%)$, and polysaccharides $(18 \%)$. The polysaccharides consisted mainly of mannose, with smaller amounts of glucose, galactose, fucose, and xylose. This relatively low amount of polysaccharides, when compared to the other cyanobacteria analyzed in the present study, may explain why $D$. circinale is the most shear stress-sensitive amongst the studied taxa (Woitzik et al.,1988). Andrade et al. (2010) observed that brown algae produced up to $49 \%$ of polysaccharides in the cell wall as a protection mechanism against chemical stress.

Zarantonello et al. (2018) studied the structure of the $R$. raciborskii cellular envelope at higher magnification and revealed that this structure was composed of two bilayered membranes: the inner or plasma membrane and the outer membrane that encloses the periplasmic space with a thin peptidoglycan layer. Hamilton et al. (2005) also observed that

$R$. raciborskii cell walls were notably thick and conspicuous which might explain the highest resistance to the shear stress in our experiments.

In recent years, several researchers have shown that $D$. circinale, $R$. raciborskii, and $M$. aeruginosa respond differently to physical and chemical stimuli in WTPs. Chow et al. (1999) demonstrated that, when M. aeruginosa was subjected to velocity gradients of up to $500 \mathrm{~s}^{-1}$ for 4 hours, neither significant changes in cellular integrity nor microcystin-LR release was observed, corroborating with the data on this study, which shows that M. aeruginosa cell damage may occur only at high-velocity gradients ( $\geq 800 \mathrm{~s}^{-1}$ corresponding to $\left.345 \mathrm{rpm}\right)$. Sun et al. (2012) observed no M. aeruginosa cell lysis or toxin release at different velocity gradients $(40,150,250$, and $500 \mathrm{rpm})$, with a mixing time of 20 minutes, and without the addition of chemicals. It is worth mentioning that in the first three velocity gradients $(40,150$, and 250 rpm) used by Sun et al. (2012), the results were similar to those found in the present study. On the other hand, divergence was observed for the highest velocity gradient (500 rpm) since there was a loss of cellular integrity at $1000 \mathrm{~s}^{-1}$ or $420 \mathrm{rpm}$ in the current experiment. 
Clemente et al. (2020) evaluated the effects of velocity gradient and mixing time of rapid and slow mixing on $D$. circinale and $R$. raciborskii cells. The rapid-mixing condition $\left(750 \mathrm{~s}^{-1}\right.$ or $325 \mathrm{rpm}$ for $60 \mathrm{~s}$ ) compromised $D$. circinale cells reducing the number of intact organisms, while $R$. raciborskii was not affected by the same hydraulic condition. Therefore, the authors also observed that $R$. raciborskii and $D$. circinale cells were differently affected by the mechanical stress of hydraulic conditions.

Li et al. (2018) compared $R$. raciborskii and M. aeruginosa membrane damage during coagulation using polyaluminum ferric chloride (PAFC). The results showed that intact $R$. raciborskii cells were removed under optimal coagulation conditions but, when high dosages ( $>10 \mathrm{mg} \mathrm{L}^{-1}$ ) were applied, toxin release increased. According to Li et al. (2018), M. aeruginosa cells only released toxin with PAFC dosages higher than $30 \mathrm{mg} \mathrm{L}^{-1}$, due to morphological and physiological differences. The results presented by Li et al. (2018) corroborate those found in the present study, also demonstrating a distinct resilience of $R$. raciborskii and $M$. aeruginosa to shear stress during the treatment process. Mucci et al. (2017) reported different cyanobacterial sensitivities due to the use of chitosan. The less sensitive strains were a member of the Chroococcales order (Microcystis sp.) and one of the Nostocales (Aphanizomenon sp.), while the most sensitive were the Nostocales (Cylindrospermopsis sp.) and the Oscillatorias (Planktothrix sp). Although the present study used no chemical additives, a similar behavior to the aforementioned studies was observed when evaluating $D$. circinale, $R$. raciborskii, and $M$. aeruginosa cell sensitivities. WTP managers and operators could consider this pattern to guide their operational procedures based on the phytoplankton composition of the raw water.

\subsection{Elaboration of the logistic regression model for odds ratio determination}

The extent of the damage to cellular integrity was evaluated using logistic regression and was found to be closely associated with gradient exposure, mixing time, and presence or absence 
of PAC for M. aeruginosa and D. circinale. This method was used because it helps evaluate the three variables simultaneously (velocity gradient, mixing time, and PAC addition), including considering their synergisms (Agresti, 2012). A logistic regression model, similar to the one proposed herein, was used by Sheng et al. (2012) to identify the response relationship between cyanobacterial blooms and environmental factors such as water quality and climatic conditions at Dianchi Lake, China. In addition to Sheng et al. (2012), several authors (Aung et al., 2019; Egorov et al., 2018; García-Pérez et al., 2016; Tornevi et al., 2016) have adopted a similar statistical approach, which allows us to infer that this method is appropriate for this study.

Table 4 shows the effects of the variables $\mathrm{X}_{1}$ (cyanobacterial species), $\mathrm{X}_{2}$ (PAC addition), $\mathrm{X}_{3}$ (velocity gradient), $\mathrm{X}_{4}$ (mixing time) and their double $\left(\mathrm{X}_{1} . \mathrm{X}_{3}, \mathrm{X}_{3} . \mathrm{X}_{2}, \mathrm{X}_{1} . \mathrm{X}_{2}, \mathrm{X}_{4} \mathrm{X}_{3}\right.$, and $\left.\mathrm{X}_{4} . \mathrm{X}_{2}\right)$ and triple interactions $\left(\mathrm{X}_{1} \cdot \mathrm{X}_{3} \cdot \mathrm{X}_{2}\right.$ and $\left.\mathrm{X}_{4} \cdot \mathrm{X}_{3} \cdot \mathrm{X}_{2}\right)$ on cellular integrity. In each different model, a new variable or group of variables was added to the null model M1 and verified if there was a sharp drop in the deviance $(p<0.05)$ and Akaike Information Criterion (AIC) values. In model M2, the null model M1 inserted with the effect of cyanobacteria species $\left(\mathrm{X}_{1}\right)$, presented the most significant reduction of deviance, showing that species have the greatest relevance for predicting the degree of association between the variables and cellular integrity. These results corroborate with Clemente et al. (2020) study, which associated cyanobacterial membrane damage on different cyanobacterial species using the same treatment conditions used in our work.

The addition of the variables $\mathrm{x}_{4}$ (PAC addition) and $\mathrm{x}_{3}$ (velocity gradient) into models $\mathrm{M} 3$ and M4, respectively, led to significant reductions in deviance, inferring that mixing time and velocity gradient are closely associated with the decrease in cellular integrity. This reinforces the findings by Clemente et al. (2020) who showed that hydraulic conditions (velocity gradient of $750 \mathrm{~s}^{-1}$ or $350 \mathrm{rpm}$ and mixing time of $60 \mathrm{~s}$ ) compromised $D$. circinale cellular 
integrity. On the other hand, M5 (M4+ PAC addition - $\mathrm{X}_{2}$ ) revealed no significant reduction in deviance and, therefore, the addition of PAC, when analyzed separately, had no impact on cellular integrity.

When considering the synergy effects of velocity gradient, mixing time, and the presence of PAC (M6 through M12), the addition of multiple interactions into the model reduced the deviance more significantly than that of model M5, implying that the impact of PAC is relevant in reducing the cellular integrity only when combined with the other two variables. Model M12, shown in Equation (2), was selected to estimate the degree of association between the variables and cellular integrity since it had the lowest residual deviance and AIC (Table 4). M12 also simultaneously fulfilled the necessary conditions for Pearson and deviance residuals, which were within their respective simulated envelope graphs (Figure 2).

In addition, it presented $\mathrm{QL}=29.29(p=0.502)$ and $\mathrm{QP}=26.21(p=0.665)$.

$$
\text { Model M12 } X_{1}+X_{3}+X_{4}+X_{1} * X_{2} * X_{3}+X_{2} * X_{3} * X_{4}
$$

Where $X_{1} * X_{2} * X_{3}$ and $X_{2} * X_{3} * X_{4}$ represent all possible interactions between variables.

Figure 2 - Pearson and deviance residuals, and their respective simulated envelope graphs.
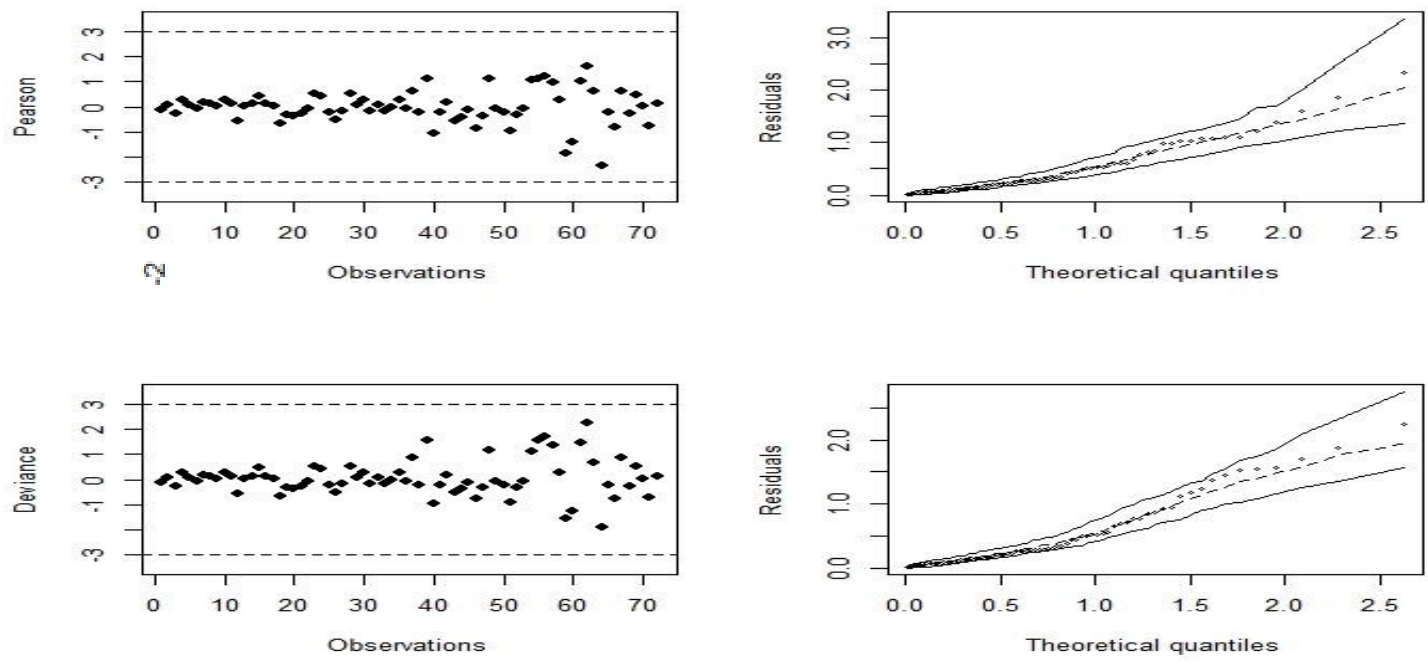
Table 4 - Analysis of deviance (ANODEV) and AIC obtained in the cellular integrity study of M. aeruginosa and D. circinale. $(\mathrm{M} i)$ : fitted model; $\left(\mathrm{X}_{1}\right)$ cyanobacteria species, $\left(\mathrm{X}_{2}\right)$ PAC addition; $\left(\mathrm{X}_{3}\right)$ velocity gradient; and $\left(\mathrm{X}_{4}\right)$ mixing time.

\begin{tabular}{|c|c|c|c|c|c|}
\hline Model & Factor & Deviance & Residual deviance & $p$ & AIC \\
\hline$\overline{\mathrm{M} 1}$ & NULL & & 1673.06 & - & 1921.87 \\
\hline M2 & $\mathrm{M} 1+\mathrm{X}_{1}$ & 1086.18 & 586.87 & $<0.001$ & 837.69 \\
\hline M3 & $\mathrm{M} 2+\mathrm{X}_{4}$ & 208.08 & 378.79 & $<0.001$ & 639.61 \\
\hline M4 & $\mathrm{M} 3+\mathrm{X}_{3}$ & 88.37 & 290.43 & $<0.001$ & 555.24 \\
\hline M5 & $\mathrm{M} 4+\mathrm{X}_{2}$ & 1.24 & 289.18 & 0.265 & - \\
\hline M6 & $\mathrm{M} 5+\mathrm{X}_{1} . \mathrm{X}_{3}$ & 28.61 & 260.57 & $<0.001$ & 530.64 \\
\hline M7 & $\mathrm{M} 6+\mathrm{X}_{3} \cdot \mathrm{X}_{2}$ & 100.82 & 159.76 & $<0.001$ & - \\
\hline M8 & $\mathrm{M} 7+\mathrm{X}_{1} . \mathrm{X}_{2}$ & 14.46 & 145.29 & $<0.001$ & - \\
\hline M9 & $\mathrm{M} 8+\mathrm{X}_{4} \mathrm{X}_{3}$ & 22.35 & 122.95 & 0.013 & 528.82 \\
\hline M10 & $\mathrm{M} 9+\mathrm{X}_{4} \cdot \mathrm{X}_{2}$ & 42.35 & 80.60 & $<0.001$ & - \\
\hline M11 & $\mathrm{M} 10+\mathrm{X}_{1} \cdot \mathrm{X}_{3} \cdot \mathrm{X}_{2}$ & 26.82 & 53.78 & $<0.001$ & - \\
\hline M12 & $\mathrm{M} 11+\mathrm{X}_{4} \cdot \mathrm{X}_{3} \cdot \mathrm{X}_{2}$ & 24.50 & 29.29 & 0.006 & 360.1 \\
\hline
\end{tabular}

\subsection{Measuring the association between cell integrity and experimental variables}

The previous results (Table 4) identified an association between higher mixing times and cell lysis. However, due to the samples 'variability, the effect of PAC addition on cyanobacterial lysis could not be identified since no significant difference $(\mathrm{P}>0,05)$ in cell damage was observed when comparing organisms subjected to those not subjected to PAC, for all times evaluated. Therefore, to better understand the effects of PAC addition, two scenarios (with and without PAC addition) were compared using the odds ratio (OR). The odds ratio represents the ratio between the odds of an event to occur in one group (i.e. samples with addition of PAC) to the odds of that event to occurs in another group (i.e. samples with no addition of PAC). Since estimated logistic regression considers the relation of variables, the estimated odds ratio $(O R)$ represents the best way of measuring the impact of PAC on the cell integrity.

Figure 3 shows the variation of the odds ratio at times $10,15,30,45$, and $60 \mathrm{~s}$ in relation to zero time in each experiment of D. circinale and M. aeruginosa, at G1 [600] s s, G2 [800] s ${ }^{-1}$, 
and G3 [1000] s ${ }^{-1}$, with and without PAC addition. The Graphs in figure 4 present two regions separated by a dotted line, which indicates an odds ratio value of one. If the odds ratio and its respective confidence interval (Error bar) fall below the dotted line, the probability of finding intact cells in the presence of PAC is lower than in the absence of PAC. On the other hand, if both the odds ratio and its confidence interval are above the dotted line, the effect of introducing PAC increases the odds of finding intact cells. When the odds ratio is over the dotted line or its confidence interval is crossing it, the odds of finding intact cells with or without PAC are equal (See a more detailed explanation in Supplementary materials). With the presence of PAC at $\mathrm{G}=[600]^{-1}$ (G1), mixing time did not change significantly the odds of finding $M$. aeruginosa intact cells when compared to identical hydraulic conditions in the absence of PAC. However, at $\mathrm{G}=[800] \mathrm{s}^{-1}(\mathrm{G} 2)$ and mixing time of $60 \mathrm{~s}$, the odds of finding intact cells were lower in the presence of PAC than in the absence of PAC. At $\mathrm{G}=[1000] \mathrm{s}^{-1}(\mathrm{G} 3)$, the odds of finding $M$. aeruginosa intact cells were reduced at all experimental times. This suggests that cell lysis events in the presence of PAC can be avoided at low-velocity gradients and, if higher gradients are required, mixing time should be reduced.

Figure 3 - Impact of velocity gradients (G1, G2, G3) and mixing times on the association between PAC application and cellular integrity (Odds ratio) of D. circinale and M. aeruginosa over 60 seconds. 

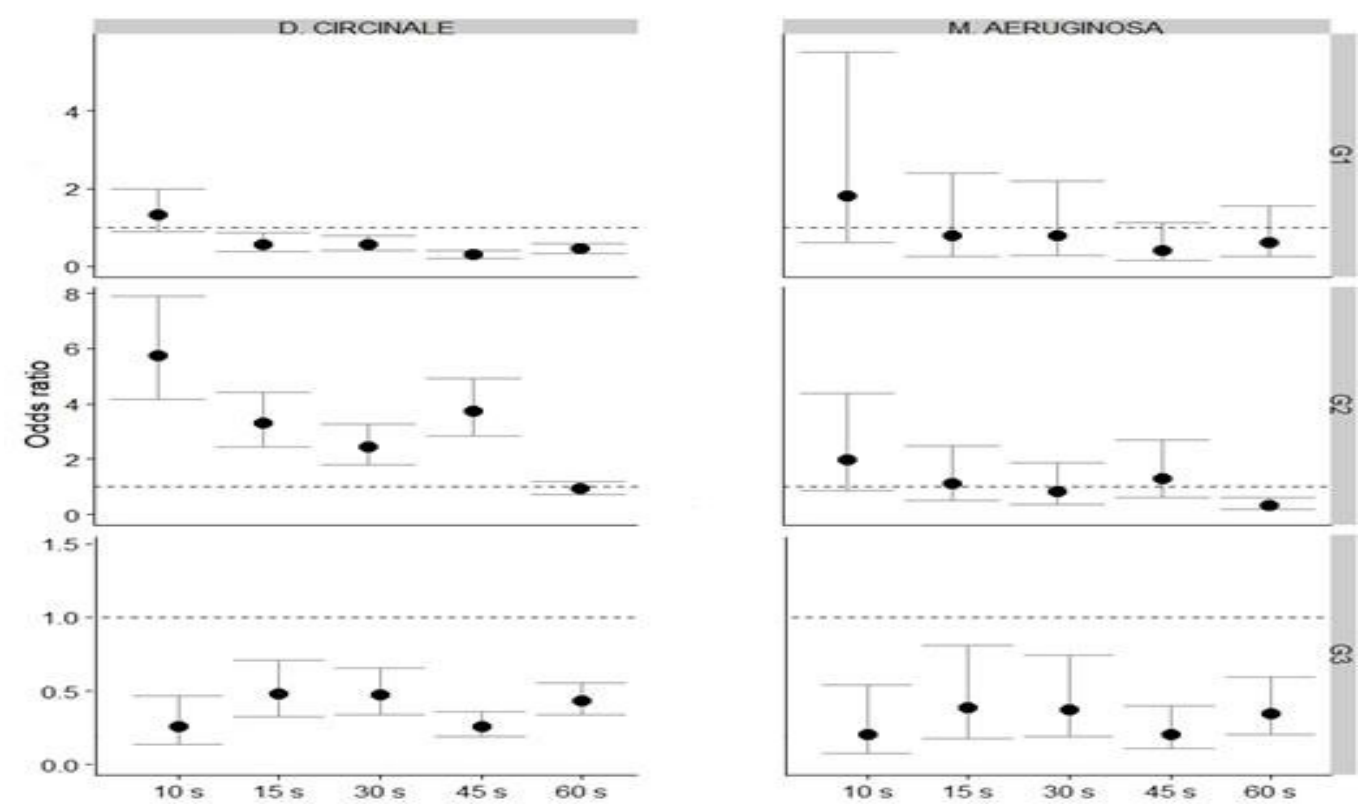

Analyzing $D$. circinale suspension exposed to $\mathrm{G}=[600] \mathrm{s}^{-1}(\mathrm{G} 1)$, the odds of finding $D$. circinale intact cells did not increase with the presence of PAC at $10 \mathrm{~s}$. However, after this mixing time (10 s), the odds of cellular integrity loss were estimated to increase by $50 \%$ when compared to the experiment in the absence of PAC. Applying $\mathrm{G}=[1000] \mathrm{s}^{-1}(\mathrm{G} 3)$ on D. circinale, the odds of finding intact cells were reduced even at the shortest mixing time (10 s). However, no conclusive results could be observed at $\mathrm{G}=[800] \mathrm{s}^{-1}(\mathrm{G} 2)$ probably due to the lower number of integral cells $(62 \pm 2.52)$ at the beginning of the experiment with PAC (Tabela 3). Since during the experiments we observed that $D$. circinale cells are extremely sensitive, we believe that this experiment already started with a large number of damaged cells

In one of the few studies reported in the literature using Dolichospermum sp. under similar conditions to the ones used in our study, Moisander et al. (2002) demonstrated that this genus is more susceptible to shear stress than other genera of filamentous cyanobacteria. In that context, although several studies have attributed the impact of WTP on cell integrity damage to the use of chemical compounds, we believe that their experimental designs may have led to 
an overestimated evaluation of cell lysis blamed on these chemical agents.

In another study that also evaluated the effects of hydraulic conditions on cyanobacterial cells, Clemente et al. (2020) observed that in a high-velocity gradient $\left(750 \mathrm{~s}^{-1}\right.$ or $\left.325 \mathrm{rpm}\right)$ and low mixing time (60 s) the odds of finding intact $D$. circinale were smaller than the odds of finding intact $R$. raciborskii. The odds of finding intact cells of $R$. raciborskii were 124 times greater than D. circinale.

Intense $D$. circinale lysis is of major concern to water companies since many authors have reported that this taxon is potentially producers of geosmin, 2-metil-isoborneol (MIB), and cyanotoxins such as saxitoxin, microcystin, cylinderspermopsin, anatoxin-a, and anatoxin- a(S) (Carmichael and Boyer, 2016; Chernova et al., 2019; Li et al., 2016; Paerl et al., 2016b; Pereyra et al., 2017). An important and concerning assessment of our finding is that the amount of adsorbent applied to the treatment could be less than needed since the addition of PAC is commonly estimated based on the concentration of dissolved metabolites (e.g., MIB, Geosmina, or toxin) before raw water enters the WTPs (Cook et al., 2001). In that sense, we believe that PAC should be dosed, in the case of $D$. circinale, considering the total metabolite concentration instead of the dissolved one.

\section{CONCLUSIONS AND RECOMMENDATIONS}

The mechanical stress imposed by the velocity gradients usually applied in WTPs was unable to compromise $R$. raciborskii cells, while the cellular integrity of $M$. aeruginosa was significantly affected only by intense velocity gradients and at relatively long exposure times. With PAC addition, a low-velocity gradient and low mixing time were enough to significantly reduce the number of $D$. circinale intact cells. The statistical analyses showed that $D$. circinale is more sensitive to mechanical stress than $R$. raciborskii and $M$. aeruginosa and that the presence of PAC intensifies this effect, indicating that WTP operation strategies should be guided by the relevant species present in the raw water. 
One of the most evident limitations of our study is that it was performed using cultured organisms in a controlled environment. Morphological differences between our strains and the ones found in the natural environment may induce a divergent response concerning variation in the working variables.

We believe that the main impact of this study is the practical operational tips or suggestions to water treatment plants operators which includes:

- to decrease the velocity gradient, time, or both during a cyanobacterial bloom, reducing the chances of further solubilizing secondary metabolites, or;

- to increase the dosage of PAC to cope with the higher concentration of toxins and T\&O compounds released during the coagulation process.

\section{ACKNOWLEDGMENTS}

The authors would like to thank the Engineering and Physical Sciences Research Council (EPSRC) [EP/P029280/1], the Coordination for the Improvement of Higher Education Personnel - CAPES [PROEX 20/2016 and PrInt 88887.311806/2018-00], the Brazilian National Research Council - CNPq [403116/2016-3 and 304164/2017-8], the Ceará Research Support Foundation - FUNCAP [ PNE-0112-00042.01.00 / 16] for funding this research. Further, the first author also acknowledges the scholarship from the Brazilian National Research Council - CNPq.

\section{REFERENCES}


Agresti, A., 2012. Categorical Data Analysis, 2nd ed. John Wley \& Sons, New Jersey. Andrade, L.R.; Leal, R.N.; Noseda, M.; Duarte, M.E.; Pereira, M.S.; Mourão, P.A.; Farina, M.; Amado Filho, G.M. 2010. Brown algae overproduce cell wall polysaccharides as a protection mechanism against the heavy metal toxicity. Marine Pollution Bulletin. 60(9):1482-8. doi: 10.1016/j.marpolbul.2010.05.004

APHA-AWWA-WEF, 2005. Standard Methods for the Examination of Water and Wastewater, 21th ed. New York.

Aung, M.T., Ferguson, K.K., Cantonwine, D.E., McElrath, T.F., Meeker, J.D., 2019. Preterm birth in relation to the bisphenol A replacement, bisphenol S, and other phenols and parabens. Environ. Res. 169, 131-138. https://doi.org/10.1016/j.envres.2018.10.037

AWWA, (American Water Works Association), ASCE, (Engineering American Society of Civil), 2012. Mixing, coagulation, and flocculation. In: Randtke, S.J.

Bakheet, B., Islam, M.A., Beardall, J., Zhang, X., McCarthy, D., 2018. Electrochemical inactivation of Cylindrospermopsis raciborskii and removal of the cyanotoxin cylindrospermopsin. J. Hazard. Mater. 344, 241-248. https://doi.org/10.1016/j.jhazmat.2017.10.024

Barbosa, M.J., Albrecht, M., Wijffels, R.H., 2003. Hydrodynamic stress and lethal events in sparged microalgae cultures. Biotechnol. Bioeng. 83, 112-120. http://dx.doi.org/10.1002/bit.10657.

Barros, M.U.G., Lopes, I.K.C., Carvalho, S.M. de C., Capelo Neto, J., 2017. Impact of filamentous cyanobacteria on the water quality of two tropical reservoirs. Rbrh. https://doi.org/10.1590/2318-0331.011716072

Bronnenmeier, R., Märkl, H., 1982. Hydrodynamic stress capacity of microorganisms.

Biotechnol. Bioeng. 24, 553-578. http://dx.doi.org/10.1002/bit.260240304. 
Bullerjahn, G.S., McKay, R.M., Davis, T.W., Baker, D.B., Boyer, G.L., D’Anglada, L. V., Doucette, G.J., Ho, J.C., Irwin, E.G., Kling, C.L., Kudela, R.M., Kurmayer, R., Michalak, A.M., Ortiz, J.D., Otten, T.G., Paerl, H.W., Qin, B., Sohngen, B.L., Stumpf, R.P., Visser, P.M., Wilhelm, S.W., 2016. Global solutions to regional problems: Collecting global expertise to address the problem of harmful cyanobacterial blooms. A Lake Erie case study. Harmful Algae 54, 223-238. https://doi.org/10.1016/j.hal.2016.01.003

Calomeni, A.J., Rodgers, J.H., 2015. Evaluation of the utility of six measures for algal (Microcystis aeruginosa, Planktothrix agardhii, and Pseudokirchneriella subcapitata) $\begin{array}{llll}\text { viability. } & \text { Ecotoxicol. } & \text { Environ. } & \text { Saf. }\end{array}$ https://doi.org/10.1016/j.ecoenv.2014.09.033

Carmichael, W.W., Boyer, G.L., 2016. Health impacts from cyanobacteria harmful algae blooms: Implications for the North American Great Lakes. Harmful Algae 54, 194-212. https://doi.org/10.1016/j.hal.2016.02.002

Chernova, E., Sidelev, S., Russkikh, I., Voyakina, E., Babanazarova, O., Romanov, R., Kotovshchikov, A., Mazur-Marzec, H., 2017. Dolichospermum and Aphanizomenon as neurotoxins producers in some Russian freshwaters. Toxicon 130, 47-55. https://doi.org/10.1016/j.toxicon.2017.02.016

Chernova, E., Sidelev, S., Russkikh, I., Voyakina, E., Zhakovskaya, Z., 2019. First observation of microcystin- and anatoxin-a-producing cyanobacteria in the easternmost part of the Gulf of Finland (the Baltic Sea). Toxicon 157, 18-24. https://doi.org/10.1016/j.toxicon.2018.11.005

Chow, C.W.K., Drikas, M., House, J., Burch, M.D., Velzeboer, R.M.A., 1999. The impact of conventional water treatment processes on cells of the cyanobacterium Microcystis aeruginosa. Water Res. 33, 3253-3262. https://doi.org/10.1016/S0043-1354(99)00051-2 
Clemente, A., Wilson, A., Oliveira, S., Menezes, I., Gois, A., Capelo-Neto, J., 2020. The role of hydraulic conditions of coagulation and flocculation on the damage of cyanobacteria. Science Of The Total Environment. 740, 139737.

Cook, D., Newcombe, G., Sztajnbok, P., 2001. The application of powdered activated carbon for MIB and geosmin removal: Predicting PAC doses in four raw waters. Water Res. https://doi.org/10.1016/S0043-1354(00)00363-8

DiBartolomeis, S.M., Mone, J.P., 2004. Apoptosis: A Four-Week Laboratory Investigation for Advanced Molecular and Cellular Biology Students. Cell Biol. Educ. 2, 275-295. https://doi.org/10.1187/cbe.03-06-0027

Dunn, J. H.; Wolk, C. P. 1970. Composition of the cellular envelopes of Anabaena cylindrica. J. Bacteriol., 103, 153-158

Duran-Encalada, J.A., Paucar-Caceres, A., Bandala, E.R., Wright, G.H., 2017. The impact of global climate change on water quantity and quality: A system dynamics approach to the US-Mexican transborder region. Eur. J. Oper. Res. 256, 567-581. https://doi.org/10.1016/j.ejor.2016.06.016

Egorov, A.I., Griffin, S.M., Ward, H.D., Reilly, K., Fout, G.S., Wade, T.J., 2018. Application of a salivary immunoassay in a prospective community study of waterborne infections. Water Res. 142, 289-300. https://doi.org/10.1016/j.watres.2018.05.030

Fan, J., Hobson, P., Ho, L., Daly, R., Brookes, J., 2014. The effects of various control and water treatment processes on the membrane integrity and toxin fate of cyanobacteria. J. Hazard. Mater. 264, 313-322. https://doi.org/10.1016/j.jhazmat.2013.10.059

García-Pérez, J., Morales-Piga, A., Gómez-Barroso, D., Tamayo-Uria, I., Pardo Romaguera, E., Fernández-Navarro, P., López-Abente, G., Ramis, R., 2016. Risk of neuroblastoma and residential proximity to industrial and urban sites: A case-control study. Environ. Int. 92-93, 269-275. https://doi.org/10.1016/j.envint.2016.04.023 
Giolo, S.R., 2017. Introdução à análise de dados categóricos com aplicações. Blusher, São Paulo.

Gumbo, R., Ross, G., Cloete, E., 2008. Biological control of Microcystis dominated harmful algal blooms. Afr. J. Biotechnol. 7, 4765-4773.

Gorham, P.R., McLachlan, J., Hammer, U.T., Kim, W.K., 1964. Isolation and culture of toxic strains of Anabaena flos-aquae (Lyngb.) de Bréb. SIL Proceedings, 1922-2010 15, 796804. https://doi.org/10.1080/03680770.1962.11895606

Haakonsson, S., Rodríguez-Gallego, L., Somma, A., Bonilla, S., 2017. Temperature and precipitation shape the distribution of harmful cyanobacteria in subtropical lotic and lentic $\begin{array}{lllll}\text { ecosystems. } & \text { Sci. } & \text { Total } & \text { Environ. } & 609,\end{array}$ https://doi.org/10.1016/j.scitotenv.2017.07.067

Hamilton, P. B.; Ley, L. M., Dean, S.; Pick, F.R. 2005. The occurrence of the cyanobacterium Cylindrospermopsis raciborskii in Constance Lake: an exotic cyanoprokaryote new to Canada. Phycologia 44(1):17-25.

Ho, L., Dreyfus, J., Boyer, J., Lowe, T., Bustamante, H., Duker, P., Meli, T., Newcombe, G., 2012. Fate of cyanobacteria and their metabolites during water treatment sludge management processes. Sci. Total Environ. 424, 232-238. https://doi.org/10.1016/j.scitotenv.2012.02.025

Jeanneret, R., Contino, M., Polin, M., 2016. A brief introduction to the model microswimmer Chlamydomonas reinhardtii. Eur. Phys. J. Spec. Top. 225, 2141-2156. http://dx.doi.org/10.1140/epjst/e2016-60065-3.

Kim, C., Lee, S. Il, Hwang, S., Cho, M., Kim, H.S., Noh, S.H., 2014. Removal of geosmin and 2-methylisoboneol (2-MIB) by membrane system combined with powdered activated carbon (PAC) for drinking water treatment. J. Water Process Eng. 4, 91-98. https://doi.org/10.1016/j.jwpe.2014.09.006 
Leupold, M.; Hindersin, S., Gust, G., Kerner, M., Hanelt, D. 2013. Influence of mixing and shear stress on Chlorella vulgaris, Scenedesmus obliquus, and Chlamydomonas reinhardtii. J. Appl. Phycol. 25, 485-495. http://dx.doi.org/10.1007/s10811-012-9882-5.

Li, H., Pei, H., Xu, H., Jin, Y., Sun, J., 2018. Behavior of Cylindrospermopsis raciborskii during coagulation and sludge storage - higher potential risk of toxin release than Microcystis aeruginosa? J. Hazard. Mater. 347, 307-316. https://doi.org/10.1016/j.jhazmat.2018.01.009

Li, X., Dreher, T.W., Li, R., 2016. An overview of diversity, occurrence, genetics and toxin production of bloom-forming Dolichospermum (Anabaena) species. Harmful Algae 54, 54-68. https://doi.org/10.1016/j.hal.2015.10.015

Lin, T.F., Chang, D.W., Lien, S.K., Tseng, Y.S., Chiu, Y.T., Wang, Y.S., 2009. Effect of chlorination on the cell integrity of two noxious cyanobacteria and their releases of odorants. J. Water Supply Res. Technol. - AQUA 58, 539-551. https://doi.org/10.2166/aqua.2009.117

Markelova, A.G., Vladimirova, M.G., Kuptsova, E.S., 2000. A comparison of cytochemical methods for the rapid evaluation of microalgal viability. Russ. J. Plant Physiol. 47, 815819. https://doi.org/10.1023/A:1026619514661

Moisander, P.H., Hench, J.L., Kononen, K., Paerl, H.W., 2002. Small-scale shear effects on heterocystous cyanobacteria. Limnol. Oceanogr. 47, 108-119. https://doi.org/10.4319/lo.2002.47.1.0108

Mucci, M., Noyma, N.P., de Magalhães, L., Miranda, M., van Oosterhout, F., Guedes, I.A., Huszar, V.L.M., Marinho, M.M., Lürling, M., 2017. Chitosan as coagulant on cyanobacteria in lake restoration management may cause rapid cell lysis. Water Res. 118, 121-130. https://doi.org/10.1016/j.watres.2017.04.020 
Naceradska, J., Pivokonsky, M., Pivokonska, L., Baresova, M., Henderson, R.K., Zamyadi, A., Janda, V., 2017. The impact of pre-oxidation with potassium permanganate on cyanobacterial organic matter removal by coagulation. Water Res. https://doi.org/10.1016/j.watres.2017.02.029

Norsker, N.-H., Barbosa, M.J., Vermuë, M.H., Wijffels, R.H., 2011. Microalgal production - a close look at the economics. Biotechnol. Adv. 29, 24-27. http://dx.doi.org/10.1016/j.biotechadv.2010.08.005.

Paerl, H.W., Gardner, W.S., Havens, K.E., Joyner, A.R., McCarthy, M.J., Newell, S.E., Qin, B., Scott, J.T., 2016a. Mitigating cyanobacterial harmful algal blooms in aquatic ecosystems impacted by climate change and anthropogenic nutrients. Harmful Algae 54, 213-222. https://doi.org/10.1016/j.hal.2015.09.009

Paerl, H.W., Qin, B., McCarthy, M.J., Newell, S.E., Havens, K.E., Gardner, W.S., Joyner, A.R., Scott, J.T., 2016b. Mitigating cyanobacterial harmful algal blooms in aquatic ecosystems impacted by climate change and anthropogenic nutrients. Harmful Algae. https://doi.org/10.1016/j.hal.2015.09.009

Pereyra, J.P.A., D’Agostino, P.M., Mazmouz, R., Woodhouse, J.N., Pickford, R., Jameson, I., Neilan, B.A., 2017. Molecular and morphological survey of saxitoxin-producing cyanobacterium Dolichospermum circinale (Anabaena circinalis) isolated from geographically distinct regions of Australia. Toxicon 138, 68-77. https://doi.org/10.1016/j.toxicon.2017.08.006

Pestana, C.J., Capelo-Neto, J., Lawton, L., Oliveira, S., Carloto, I., Linhares, H.P., 2019. The effect of water treatment unit processes on cyanobacterial trichome integrity. Sci. Total Environ. 659, 1403-1414. https://doi.org/10.1016/j.scitotenv.2018.12.337

Qi, J., Lan, H., Liu, R., Miao, S., Liu, H., Qu, J., 2016. Prechlorination of algae-laden water: The effects of transportation time on cell integrity, algal organic matter release, and chlorinated disinfection byproduct formation. Water Res. 102, 221-228. https://doi.org/10.1016/j.watres.2016.06.039 
Qian, F., Dixon, D.R., Newcombe, G., Ho, L., Dreyfus, J., Scales, P.J., 2014. The effect of pH on the release of metabolites by cyanobacteria in conventional water treatment processes. Harmful Algae 39, 253-258. https://doi.org/10.1016/j.hal.2014.08.006

Sheng, H., Liu, H., Wang, C., Guo, H., Liu, Y., Yang, Y., 2012. Analysis of cyanobacteria bloom in the Waihai part of Dianchi Lake, China. Ecol. Inform. https://doi.org/10.1016/j.ecoinf.2012.03.007

Sinha, R., Pearson, L.A., Davis, T.W., Burford, M.A., Orr, P.T., Neilan, B.A., 2012. Increased incidence of Cylindrospermopsis raciborskii in temperate zones - Is climate change responsible? Water Res. 46, 1408-1419. https://doi.org/10.1016/j.watres.2011.12.019

Sun, F., Pei, H.Y., Hu, W.R., Ma, C.X., 2012. The lysis of Microcystis aeruginosa in AlCl 3 coagulation and sedimentation processes. Chem. Eng. J. 193-194, 196-202. https://doi.org/10.1016/j.cej.2012.04.043

Szlag, D.C., Sinclair, J.L., Southwell, B., Westrick, J.A., 2015. Cyanobacteria and cyanotoxins occurrence and removal from five high-risk conventional treatment drinking water plants. Toxins (Basel). 7, 2198-2220. https://doi.org/10.3390/toxins7062198

Tornevi, A., Simonsson, M., Forsberg, B., Säve-Söderbergh, M., Toljander, J., 2016. Efficacy of water treatment processes and endemic gastrointestinal illness - A multi-city study in Sweden. Water Res. 102, 263-270. https://doi.org/10.1016/j.watres.2016.06.018

Trenberth, K.E., Dai, A., Van Der Schrier, G., Jones, P.D., Barichivich, J., Briffa, K.R., Sheffield, J., 2014. Global warming and changes in drought. Nat. Clim. Chang. 4, 1722. https://doi.org/10.1038/nclimate2067

Tsai, K.P., 2015. Effects of two copper compounds on Microcystis aeruginosa cell density, membrane integrity, and microcystin release. Ecotoxicol. Environ. Saf. 120, 428-435. https://doi.org/10.1016/j.ecoenv.2015.06.024

Wang, C.; Lan, C.Q. 2018. Effects of shear stress on microalgae - A review. Biotechnology Advances 36 986-1002 
Woitzik, D.; Weckesser, J.; Jurgens, U.J. 1988. Isolation and characterization of cell wall components of the unicellular cyanobacterium synechococcus sp. PCC 6307. Microbiology 134, 619-627. http://dx.doi.org/10.1099/00221287-134-3-619.

Xie, P., Chen, Y., Ma, J., Zhang, X., Zou, J., Wang, Z., 2016. A mini-review of preoxidation to improve coagulation. Chemosphere 155, 550-563. https://doi.org/10.1016/j.chemosphere.2016.04.003

Zamyadi, A., Henderson, R., Stuetz, R., Hofmann, R., Ho, L., Newcombe, G., 2015. Fate of geosmin and 2-methylisoborneol in full-scale water treatment plants. Water Res. 83, 171183. https://doi.org/10.1016/j.watres.2015.06.038

Zarantonello, V.; Silva, T.P.; Noyma, N.P.; Gamalier, JP; Mello, M.M.; Marinho; M.M.; Melo, R.C.N. (2018) The Cyanobacterium Cylindrospermopsis raciborskii (CYRF-01) Responds to Environmental Stresses with Increased Vesiculation Detected at Single-Cell Resolution. Frontiers in Microbiology, 9:272. DOI: 10.3389/fmicb.2018.00272

Zhou, S., Shao, Y., Gao, N., Zhu, S., Li, L., Deng, J., Zhu, M., 2014. Removal of Microcystis aeruginosa by potassium ferrate (VI): Impacts on cells integrity, intracellular organic matter release, and disinfection by-products formation. Chem. Eng. J. 251, 304-309. https://doi.org/10.1016/j.cej.2014.04.081 
Graphical abstract

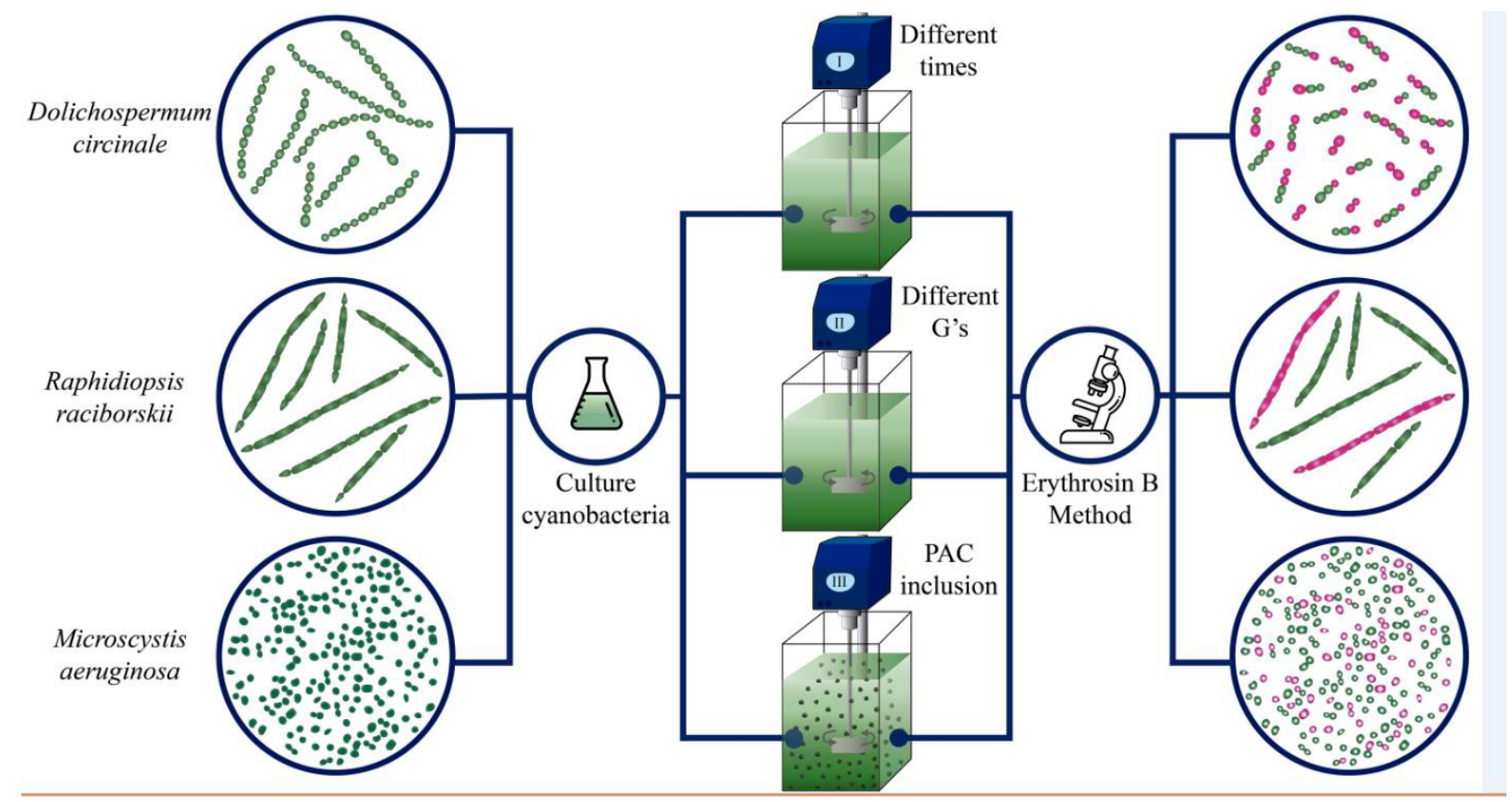




\section{Cultivation}
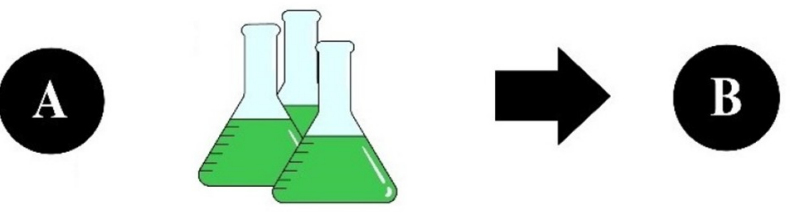

\section{Reactors}
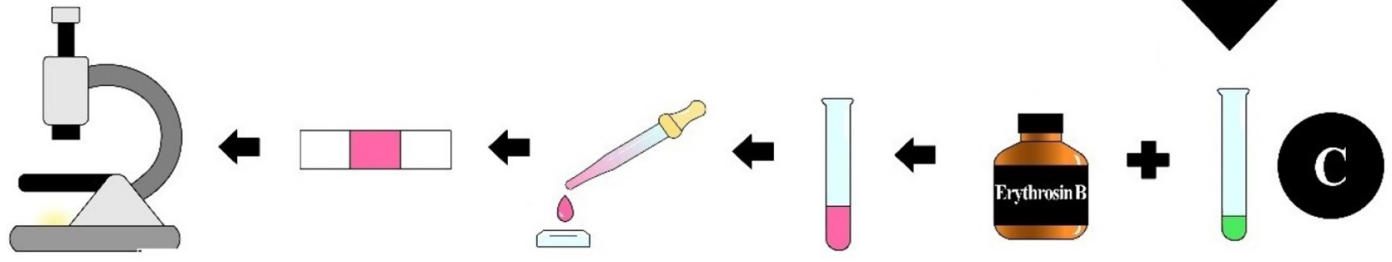

Cell Integrity Assessment

Figure 1 


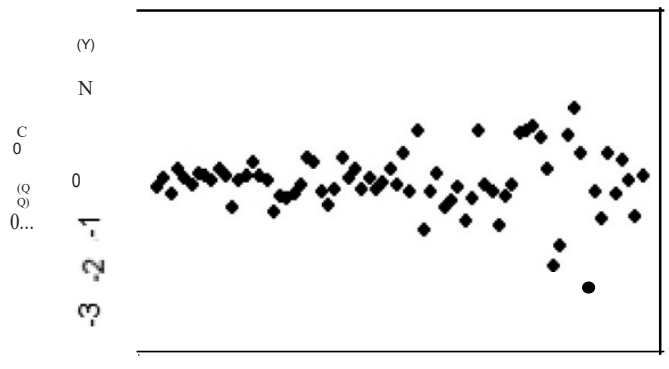

$\begin{array}{llllllll}0 & 10 & 20 & 30 & 40 & 50 & 60 & 70\end{array}$

Observations
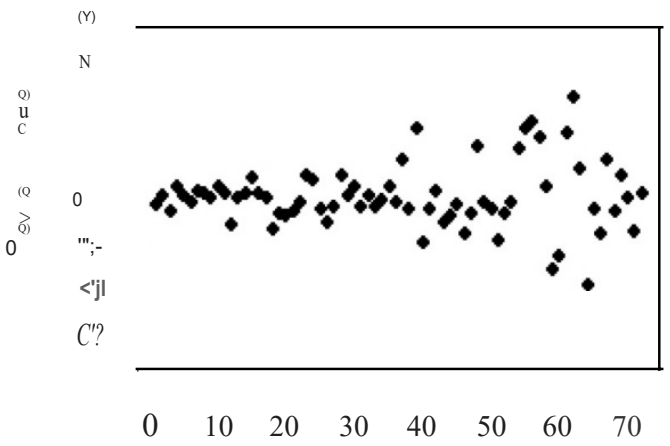

Observations

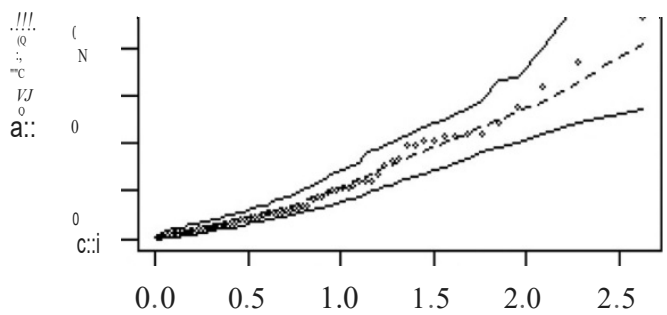

Theoretical quantiles

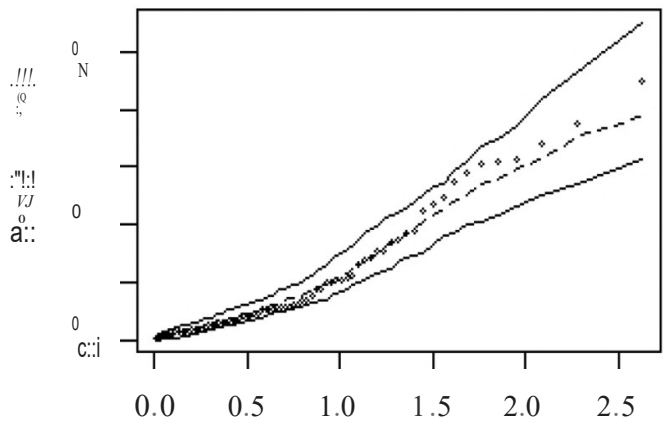

Theoretical quantiles 
Figure 2 

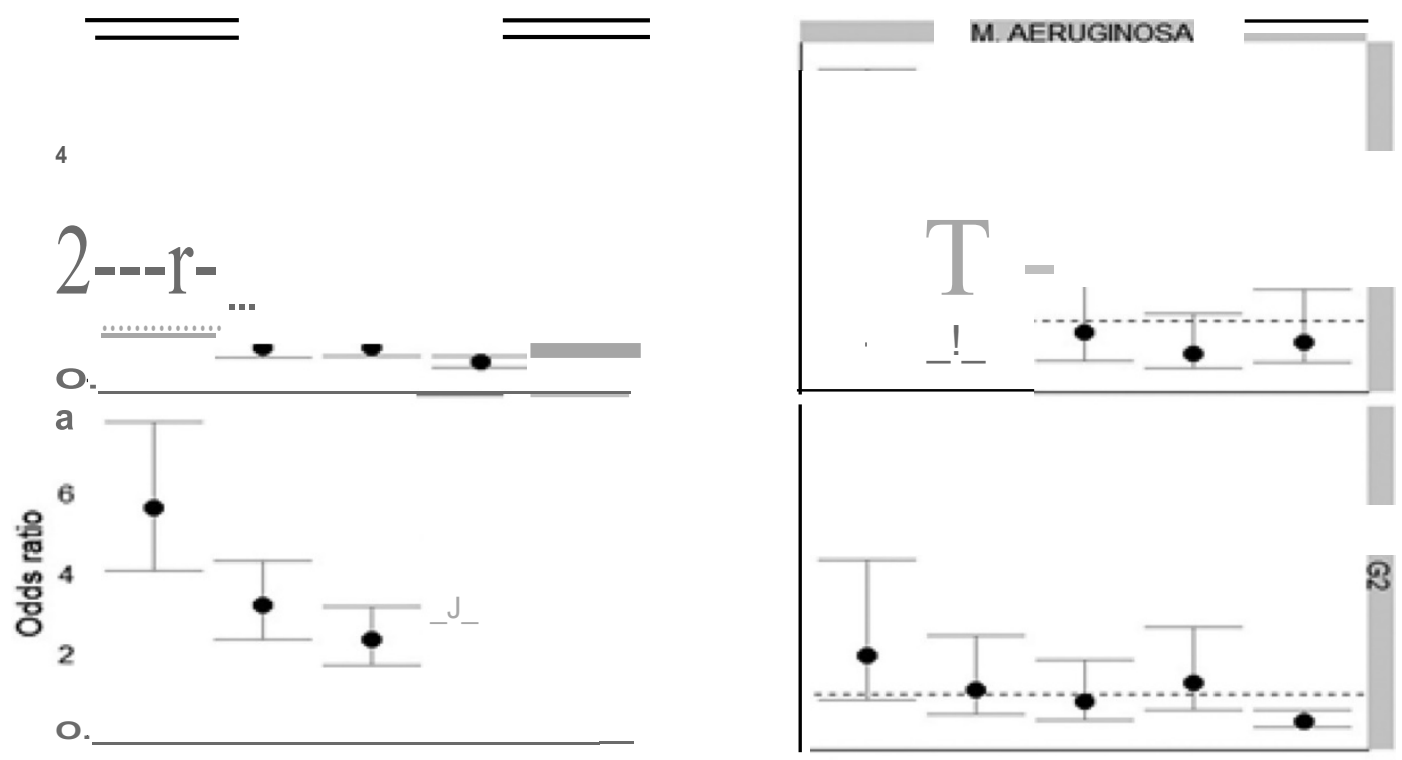

"1,5 -

=..O- -
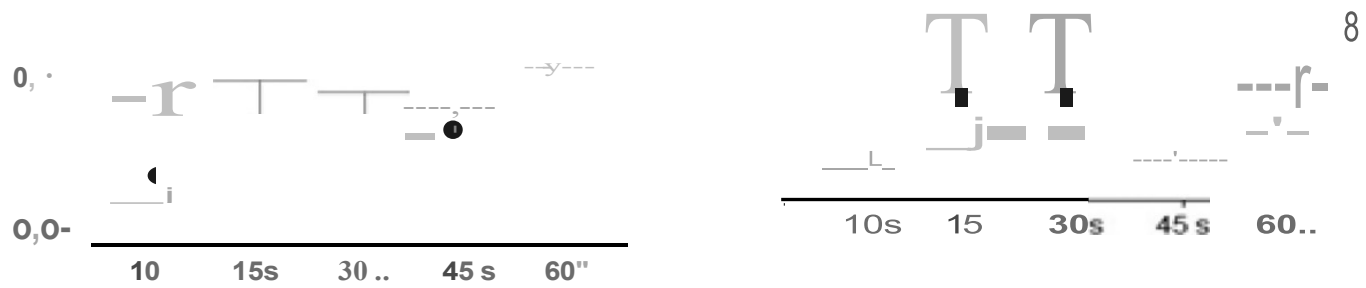
Figure 3 


\section{Supplementary materials}

\section{Data analyses}

Statistical analyses to evaluate the hypothesis of the association between the variables (cyanobacteria species, velocity gradient interval, mixing time, and with or without PAC addition) and cell integrity was performed using RStudio and modified data analysis methodology (Clemente et al., 2020). Details of this methodology can be found in the supplemental materials. The response variable (Cell integrity) was dichotomized, allowing two possible results: cell integrity preserved or not preserved. Data analysis was performed in three steps (Figure 1):

1. Identifying Association: Fisher's exact test was performed using appropriate contingency tables (Supplementary materials). The association was confirmed when $p<0.05$;

2. Logistic Regression: Only the species that had some level of association in Fisher's exact test $(p<0.05)$ were included in the logistic regression model. Cyanobacteria species $\left(\mathrm{X}_{1}\right)$, use of PAC $\left(\mathrm{X}_{2}\right)$, velocity gradient $\left(\mathrm{X}_{3}\right)$, and mixing time $\left(\mathrm{X}_{4}\right)$ were considered as explanatory categorical variables. The selected model and the table with the analysis of deviance (ANODEV) were obtained through the Stepwise method. The ANODEV table contains the effects of the inclusion of each explanatory variable $\left(\mathrm{X}_{1}, \mathrm{X}_{2}, \mathrm{X}_{3}\right.$, or $\left.\mathrm{X}_{4}\right)$ in the null model (with no explanatory variables). The aforementioned effects were evaluated using the deviance values and their residuals as well as the Akaike Information Criterion (AIC). The importance of including the variable in the model was verified when significant residual $(p<0.05)$ was observed. The best model was considered the one with the lowest AIC and residual of deviance. To ensure the quality of the proposed model fit, the residues were tested by checking if they simultaneously met the following conditions (Giolo, 2017):

I. Pearson and deviance residuals are randomly distributed and do not exceed values of \pm 3.0 ;

II. Pearson and deviance residuals are contained within the simulated envelopes; 
III. Chi-square statistic likelihood ratio (QL) and Pearson's chi-square statistic $(\mathrm{QP})$ present $p$-value $>0.05$.

3. Measuring the association: The estimated odds were calculated by applying exponential to the estimated coefficients $\left(\widehat{\beta_{l}}\right)$ in an equation obtained in step 2 . The odds of each experimental time $(10,15,30,45$, and $60 \mathrm{~s})$ was divided by the odds of the initial time ( 0 s), obtaining the estimated Odds Ratio. The same result can be obtained by applying exponential to the linear combination of the transpose of vector $X_{\mathrm{i}}\left(\mathrm{e} . \mathrm{g}\right.$., $\left.X_{i}^{t}\right)$ and to vector $\widehat{B}$ containing the estimated $\widehat{\beta}_{\imath}\left(\exp \left[X_{i}^{t} \cdot \hat{B}\right]\right)$. Considering that $\widehat{B}$ is asymptotically a multivariate normal and that the linear combination $(\mathrm{X} . \hat{B})$ is also an asymptotically multivariate normal, the confidence interval $(\alpha=0.1 \%)$ for Odds Ratio can be estimated by Equation 1:

$$
C I[\text { Odds Ratio }]=\exp \left[X_{i}^{t} \cdot \hat{B} \pm z_{\alpha / 2} \sqrt{X_{i} I_{F}^{-1} X_{i}^{t}}\right]
$$

Where

$\widehat{\mathrm{B}}=$ Vector containing the odds $\widehat{\beta}_{l}$ estimated by the model obtained in step 2;

$\mathrm{X}_{\mathrm{i}}=$ Vector that is equal to 1 when the respective $\widehat{\beta}_{l}$ is important for calculating the Odds Ratio and, otherwise, is equal to 0;

$z_{\alpha / 2}=100(1-0.5 \alpha)$, percentile of the standard normal distribution;

$\mathrm{I}_{\mathrm{F}}^{-1}=$ Inverse of the Fisher information matrix.

The considerations were given as follows:

- Odds Ratio $>1$ and CI $\notin 1$ : there is an increase in the Odds of intact cells from each experimental time in relation to the initial time (Region 1 in Figure 2);

- Odds Ratio $<1$ and CI $\notin 1$ : there is a decrease in the Odds of intact cells from each experimental time in relation to the initial time (Regin 3 in Figure 2), and; - Odds Ratio $=1$ or $\mathrm{CI} \in 1$ : The Odds of intact cells from each experimental time in relation to the initial time are the same(Region 2,in Figure 2). 
Figure 1 - Statistical analysis workflow

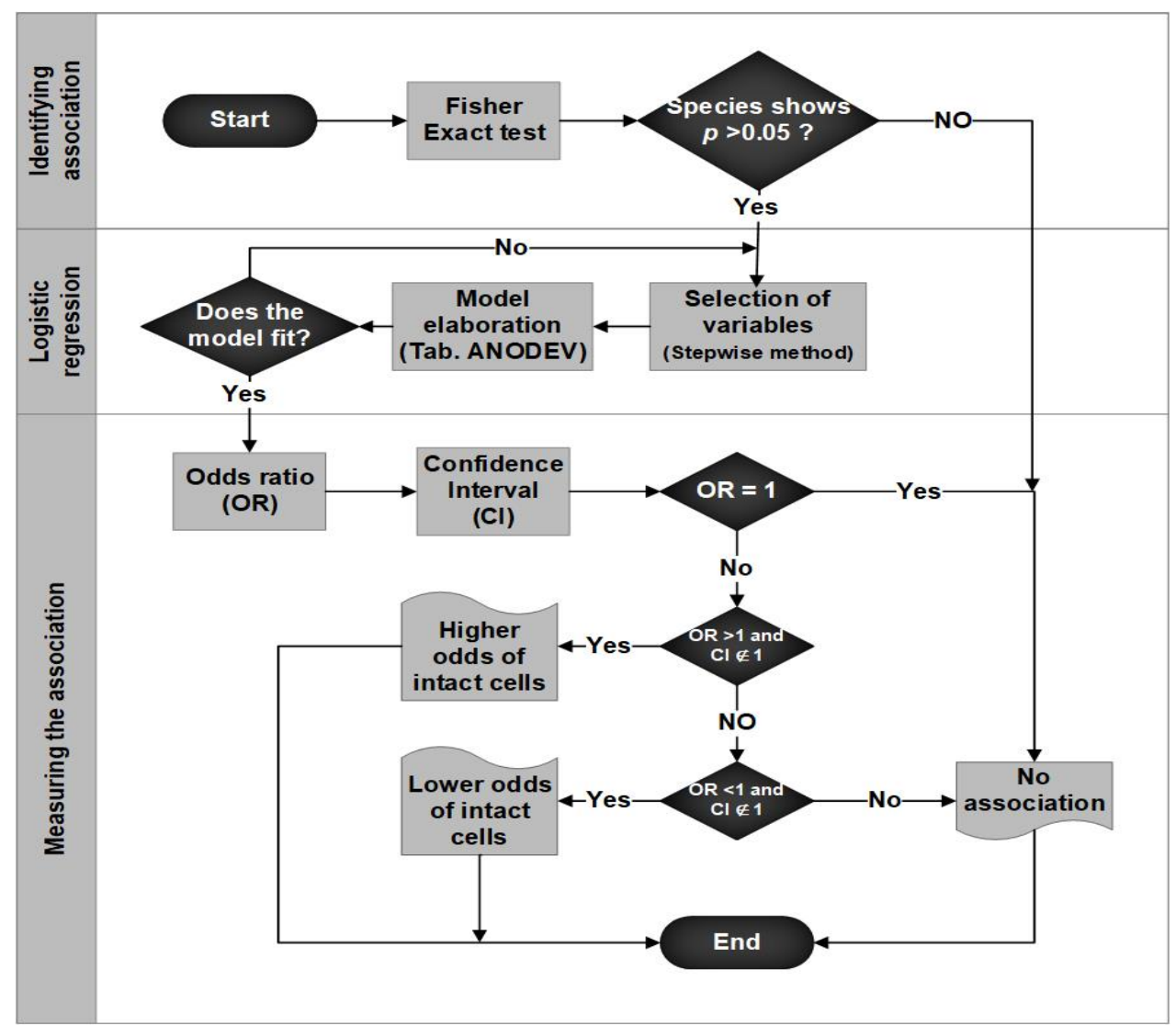


Figure 2 - Interpretation of the OR graph. The dotted line represents OR $=1$. Region 1 exemplifies the times when the probability of finding intact cells in experiments with CAP was greater than in those without CAP. Region 2 exemplifies the times when the introduction of PAC was not significant, as the probabilities of finding healthy cells are equal in the presence or absence of PAC and in Region 3 it exemplifies the times when the presence of PAC reduced as chances of entering whole cells.

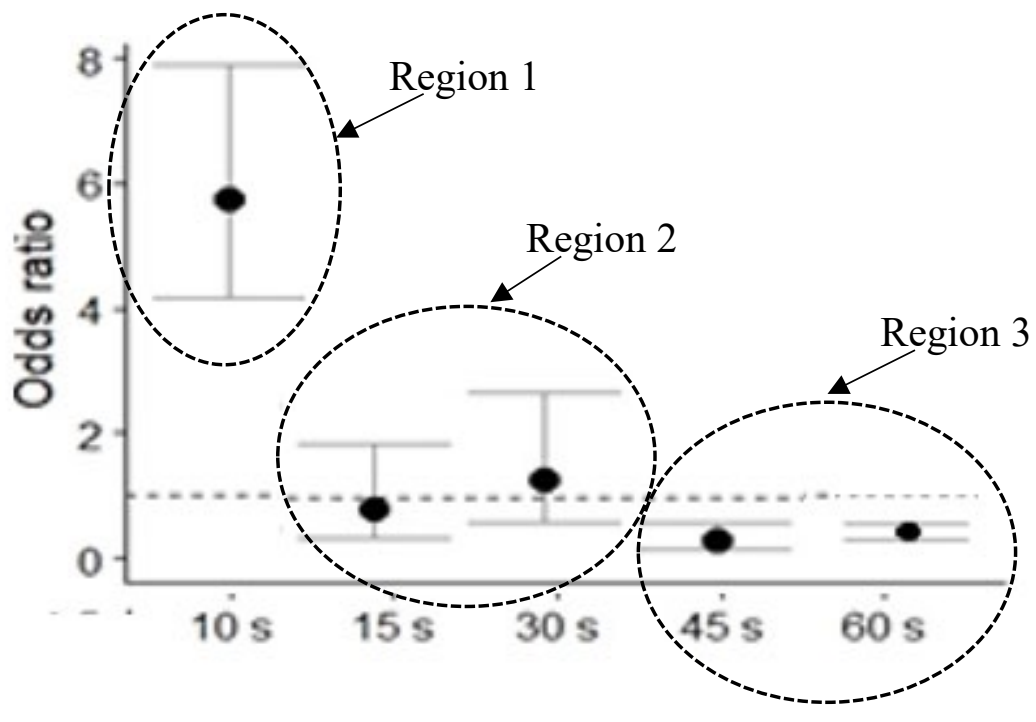

The contingency tables can be obtained as follows:

Table A1 - Example of Contingency Tables 2 by 2

\begin{tabular}{|c|c|c|c|}
\hline \multirow{2}{*}{ Time of mix } & $\begin{array}{l}\text { Mean of intact cy } \\
\text { species "K" at vel }\end{array}$ & $\begin{array}{l}\text { acterial cells of } \\
\text { gradient "J" } \mathrm{s}^{-1}\end{array}$ & \multirow[t]{2}{*}{ Total } \\
\hline & Yes & No (100 - Yes) & \\
\hline $\mathrm{t}_{\mathrm{i}}$ & $\mathrm{n}_{11}$ & $\mathrm{n}_{12}$ & $\mathrm{~N}_{1^{*}}=\mathrm{n}_{11}+\mathrm{n}_{12}$ \\
\hline $0 \mathrm{~s}$ & $\mathrm{n}_{21}$ & $\mathrm{n}_{22}$ & $\begin{array}{l}\mathrm{N}_{2^{*}}=\mathrm{n}_{21}+\mathrm{n}_{22} \\
\mathrm{~N}=\mathrm{N}_{1^{*}}+\mathrm{N}_{2^{*}}\end{array}$ \\
\hline \multirow[t]{2}{*}{ Total } & $\mathrm{N} *_{1}=\mathrm{n}_{11}+\mathrm{n}_{21}$ & $\mathrm{~N} *_{2}=\mathrm{n}_{11}+\mathrm{n}_{21}$ & or \\
\hline & & & $\mathrm{N}=\mathrm{N} *_{1}+\mathrm{N} *_{2}$ \\
\hline
\end{tabular}

Where:

- "K" represents Cyanobacteria species (Ma, Dc, and Rr);

- "J" represents velocity gradient $\left(600,800\right.$ and $\left.1000 \mathrm{~s}^{-1}\right)$;

- $\mathrm{t}_{\mathrm{i}}$ represents the time of mix;

- $\mathrm{n}_{11}$ and $\mathrm{n}_{21}$ represents the number of intact cells at $\mathrm{t}_{\mathrm{i}}$ and $0 \mathrm{~s}$, respectively;

- $\mathrm{n}_{12}$ and $\mathrm{n}_{22}$ represents the number of not intact cells at $t_{\mathrm{i}}$ and $0 \mathrm{~s}$, respectively (100- Yes);

- $\mathrm{N}_{*_{1}}, \mathrm{~N} *_{2}, \mathrm{~N}_{1 *}, \mathrm{~N}_{2 *}$ represents the partial total of columns $\left(\mathrm{N}_{*_{1}}, \mathrm{~N}_{*_{2}}\right)$ and rows $\left(\mathrm{N}_{1 *}, \mathrm{~N}_{2 *}\right)$

- $\quad \mathrm{N}$ represents the total

For example, in table $4(\mathrm{~K}=\mathrm{Dc})$, for velocity gradient $800 \mathrm{~s}^{-1}\left(\mathrm{~J}=800 \mathrm{~s}^{-1}\right)$ and mixing time of 45 $\mathrm{s}\left(\mathrm{t}_{\mathrm{i}}=45 \mathrm{~s}\right)$, the contingency table is at it follows (Table A2):

Table A2 - Example of Contingency Tables 2 by 2 for Table 4 


\begin{tabular}{|c|c|c|c|}
\hline \multirow[t]{2}{*}{ Time of mix } & \multicolumn{2}{|c|}{$\begin{array}{l}\text { Mean of intact cyanobacterial cells of Dc } \\
\text { species at velocity gradient } 800 \mathrm{~s}^{-1}\end{array}$} & \multirow[t]{2}{*}{ Total } \\
\hline & Yes & No (100 - Yes) & \\
\hline $45 \mathrm{~s}$ & 40 & 60 & 100 \\
\hline $0 \mathrm{~s}$ & 62 & 38 & 100 \\
\hline Total & 102 & 98 & 200 \\
\hline
\end{tabular}

All other tables follow the same logic.

\section{Continuous stirred reactor characteristics}

The continuous stirred reactors used is a piece of equipment commonly applied for water treatment analysis to perform coagulation, flocculation, and sedimentation assays (Figure A). The reactors are constituted by six jars made of acrylic with a total volume of $2 \mathrm{~L}$. Each reactor was agitated by a stainless-steel blade with dimensions of $8 \times 3 \mathrm{~cm}$ and height adjustment.

Figure A - Continuous stirred reactors used to evaluate the impacts of velocity gradient, mixing time, and PAC addition on M. aeruginosa, D. circinale, and $R$. raciborskii cell integrity.

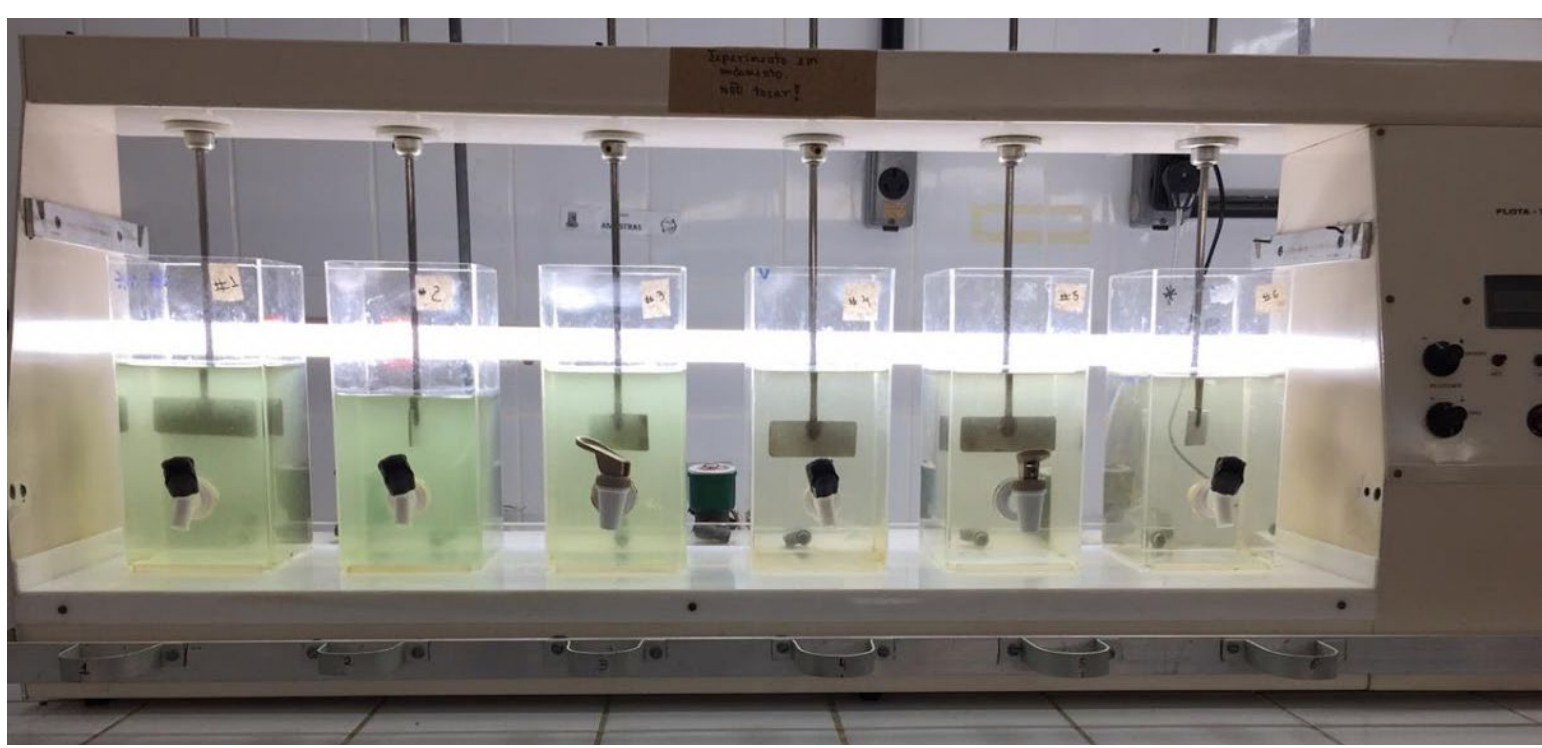

The formula used for the calculation of the velocity gradient based on the RPM was:

$$
y=2.6735 x-120.21
$$

Where:

y: Calculated velocity gradient $\left(\mathrm{s}^{-1}\right)$;

$\mathrm{x}$ : paddle rotation in rpm. 
Basic dechlorinated water quality data

\begin{tabular}{|l|c|}
\hline \multicolumn{1}{|c|}{ Parameter } & Value \\
\hline $\mathrm{pH}$ & 7.42 \\
\hline True Color & 5 \\
\hline Total hardness & 123.75 \\
\hline Alkalinity & 76.75 \\
\hline Chlorides & 148.75 \\
\hline Turbidity & 0.68 \\
\hline
\end{tabular}

